\title{
Konten Hadis di Media Sosial: Studi Content Analysis dalam Jejaring Sosial pada Akun Lughoty.com, @RisalahMuslimID, dan @thesunnah_path
}

\author{
Maulana Wahyu Saefudin', Agus Suyadi Raharusun², Muhamad Dede \\ Rodliyana $^{3}$ \\ 1,2,3 Fakultas Ushuluddin UIN Sunan Gunung Djati Bandung, Indonesia \\ almahdin7@gmail.com, agussuyadi@uinsgd.ac.id,rodliyana76@gmail.com
}

\begin{abstract}
This research is motivated by the fact that the forms of hadith content that are spread on Lughoty.com, @RisalahMuslimID, and @thesunnah_path accounts are not always complete in the structure of a hadith and are not always considered authentic. This study aims to discuss the content of hadith on social media in social networks Facebook, Twitter, and Instagram with the sample accounts Lughoty.com, @RisalahMuslimID, and @thesunnah_path. This research is a qualitative type through a literature study that analyzes hadith content on social media using content analysis methods. The results and discussion of this study are an understanding of contextualization of hadith in the 21st century with technological advances in the information sector, and the form of hadith content on Lughoty.com, @RisalahMuslimID, and @thesunnah_path accounts does not always have a complete structure in a hadith. This study concludes that the hadith content found on social media in the Facebook, Twitter, and Instagram social networks on the Lughoty.com, @RisalahMuslimID, and @thesunnah_path accounts are not always judged to be authentic or hasan nor are all hadiths found on social networks. have completeness so that it is necessary to re-examine the obtained hadith to find the truth about the quality of a hadith.
\end{abstract}

Keywords: Content analysis, Hadith content, Social media.

\begin{abstract}
Abstrak
Penelitian ini dilatarbelakangi adanya bentuk konten hadis yang tersebar pada akun Lughoty.com, @RisalahMuslimID, dan @thesunnah_path tidak selalu lengkap dalam struktur sebuah hadis dan tidak selalu dinilai shahih. Penelitian ini bertujuan untuk membahas konten hadis di media sosial dalam jejaring sosial Facebook, Twitter, dan Instagram
\end{abstract}


dengan sampel akun Lughoty.com, @RisalahMuslimID, dan @thesunnah_path. Penelitian ini merupakan jenis kualitatif melalui studi pustaka yang melakukan analisis terhadap konten hadis di media sosial dengan menggunakan metode analisis isi. Hasil dan pembahasan penelitian ini adalah pemahaman terhadap hadis secara kontekstualisasi pada abad ke-21 dengan kemajuan teknologi di bidang informasi marak dilakukan, dan bentuk konten hadis pada Akun Lughoty.com, @RisalahMuslimID, dan @thesunnah_path tidak selalu memiliki kelengkapan struktur dalam sebuah hadis. Penelitian ini menyimpulkan bahwa konten-konten hadis yang terdapat di media sosial dalam jejaring sosial Facebook, Twitter, dan Instagram pada akun Lughoty.com, @RisalahMuslimID, dan @thesunnah_path tidak selalu dinilai shahih ataupun hasan begitu pula tidak semua hadis yang terdapat pada jejaring sosial memiliki kelengkapan sehingga perlu diteliti kembali hadis yang didapat untuk menemukan kebenaran atas kualitas sebuah hadis.

Kata kunci: Content analysis, Konten hadis, Media sosial.

\section{Pendahuluan}

Media sosial adalah media online yang sudah merombak korelasi dan komunikasi individu di segala penjuru dunia (Edosomwan, Prakasan, Kouame, Watson, \& Seymour, 2011). Media sosial mempunyai arti sebuah alat yang digunakan seseorang untuk berkomunikasi dengan orang lain dan komunikasi tersebut tentunya akan memberikan kontribusi terhadap lawan komunikasinya. Terlepas kontribusi itu baik atau buruk, karena interaksi seseorang tidak bisa dilepaskan dari dua hal tersebut, yakni baik atau buruk (Kosasih, Raharusun, Dalimunthe, \& Kodir, 2020). Satu di antara banyaknya perkembangan media ini adalah dengan munculnya jejaring sosial, yang merupakan cara baru untuk berkomunikasi dalam kelompok, komunitas, terhimpun dalam satu laman, situs dan aplikasi internet berskala luas (Aris, Hasanah, \& Iskandar, 2016). Jenis-jenis jejaring sosial sangat banyak, antara lain Facebook, Twitter, dan Instagram. Jejaring sosial telah menjadi praktik sehari-hari dalam kehidupan manusia.

Belakangan ini, media sosial telah memengaruhi banyak orang dalam aspek komunikasi manusia (Edosomwan, Prakasan, Kouame, Watson, \& Seymour, 2011), termasuk segi informasi. Akibat dari kehadiran internet dewasa ini memberikan akses yang mudah bagi masyarakat untuk mendapat segala bentuk informasi apapun yang diinginkan, baik itu berasal dari dalam atau luar negeri (Fahmi, Aeres, Wibawa, \& Dalimunthe, 
2021). Bagaimanapun, media sosial berperan penting sebagai sumber informasi bagi para pengguna internet. Perkembangan teknologi komunikasi yang pesat memungkinkan bagaimana orang dapat mengirim atau memposting dan menerima informasi dari media sosial.

Mengingat sifatnya yang terbuka, informasi yang dibuat dan diumumkan di media sosial memungkinkan informasi yang didapat tidak selalu benar adanya. Pengguna media sosial adalah bangsa dan individu yang dapat menghasilkan informasi apapun pada berbagai layanan media sosial (Luthfie, 2016).

Akibatnya, beberapa informasi yang dimunculkan dan dikonsumsi publik menjadi tidak terkendali, baik dari sisi pengetahuan maupun di tingkat nasional, dan beberapa informasi terbukti dipalsukan karena bersumber dari media yang tidak terpercaya. Menurut Syuhudi Ismail dalam bukunya yang berjudul "Kaidah Kesahihan Sanad Hadis," yang dikutip oleh M. Zia al-Ayyubbi, dalam kajian ilmu hadis, ketika ditemukan sebuah informasi (hadis) dan penyebar informasi tersebut (rawi) disampaikan oleh seseorang yang tidak kredibel, maka informasi tersebut perlu untuk dipertanyakan kebenarannya (Al-Ayyubi, 2018, p. 149).

Sama halnya dengan mengirim informasi atau memposting konten yang berkaitan dengan sabda Rasulullah Saw. Dalam kajian ilmu hadis, berdasarkan kualitas sebuah hadis terbagi menjadi tiga macam, yaitu: shahih, hasan, dan dha'if (Umara, 2021). Hadis shahih merupakan hadis yang sanadnya bersambung sampai ke Rasul, rawinya dhabit (kuat hafalan), tidak syadz dan tidak ada 'illat atau kecacatan pada matan dan sanadnya (Solahudin \& Suyadi, 2009). Hadis hasan hampir sama dengan hadis shahih, namun perbedaannya adalah kualitas hafalan rawi hadis hasan tidak sekuat hadis shahih. Sedangkan hadis dha'if adalah hadis yang tidak memenuhi persyaratan hadis shahih dan hadis hasan. Oleh karena itu, hadis yang kualitasnya dha'if tidak bisa dijadikan hujjah (dalil atau hukum). Namun dalam beberapa kasus, menurut ulama hadis, hadis dha' if boleh diamalkan selama tidak terlalu lemah dan untuk fadhail amal (Ferdiansyah, 2017).

Dilihat dari penjelasannya, konten hadis yang tersebar di media sosial tidak sepenuhnya bisa dijadikan dalil untuk menjalankan sunnah Rasul, kecuali jika kita sendiri yang mencari kebenaran atas kualitas hadis tersebut. Tidak sedikit kasus di media sosial yang memposting konten hadis, namun hadis tersebut setelah diteliti kembali ternyata hadis dha'if. Dampaknya, kita yang mengirimkan atau menerima informasi tersebut mendapatkan dan menyebarkan kesesatan kepada orang lain.

Berbagai penelitian terdahulu telah membahas mengenai hadis yang ada di media sosial. Antara lain al-Ayyubi, M. Z. (2018) yang berjudul "Etika Bermedia Sosial dalam Menyikapi Pemberitaan Bohong (Hoax) Perspektif Hadis," Jurnal Studi Ilmu-Ilmu al-Qur'an dan Hadis. Penelitian 
ini menyampaikan sikap dan etika pengguna internet di media sosial dengan pendekatan hadis. Penelitian ini menyimpulkan bahwa dengan menyampaikan informasi secara jujur, hal ini memberikan suatu kontribusi baik, yang paling minimal adalah tidak adanya kegaduhan yang diakibatkan oleh pemberitaan bohong di media sosial (Al-Ayyubi, 2018). Saputra, T. A. \& Suryadilaga, M. A. (2020) berjudul "Perkembangan dan Kesahihan Hadis dari Awal Islam Hingga Zaman Post Truth," Jurnal Ilmiah Al-Mu'ashirah. Penelitian ini membahas tentang sejarah perkembangan hadis dari zaman Nabi Saw. hingga era global yang mana hadis telah ada dalam bentuk website dan aplikasi yang dapat digunakan melalui smartphone. Penelitian ini menyimpulkan bahwa kebenaran tentang hadis pada era post truth dilatarbelakangi oleh kepentingan politik begitu juga penggunaan konten yang bertujuan materil, sehingga kebenaran hadis harus ditinjau kembali (Saputra \& Suryadilaga, 2020). Sumadi, E. (2016) berjudul "Dakwah dan Media Sosial: Menebar Kebaikan Tanpa Diskriminasi," Jurnal Komunikasi Penyiaran Islam. Penelitian ini membahas tentang konsep dakwah menurut Islam dan peran media sosial dalam berdakwah. Penelitian ini menyimpulkan bahwa media sosial dinilai efektif sebagai sarana berdakwah, namun harus memperhatikan etika dan norma-norma bermedia sosial (Sumadi, 2016).

Penelitian terdahulu bermanfaat dalam penyusunan kerangka berpikir penelitian ini. Media sosial merupakan sebuah media online, di mana para penggunanya melalui aplikasi berbasis internet dapat berbagi, berpartisipasi, dan menciptakan konten berupa blog, wiki, forum, jejaring sosial, dan ruang dunia virtual yang disokong oleh teknologi multimedia yang kian canggih (Mulyati, 2014). Dilihat dari kelebihan media sosial dalam penyebaran informasi yang cepat dan mudah untuk mengirimkan informasi. Namun, isu utama seputar penggunaan media sosial sebagai sumber informasi tersebut adalah bagaimana masyarakat menilai kredibilitas sumber informasi tersebut (Westerman, Spence, \& Heide, 2012). Penentuan baik atau buruknya dalam menyampaikan informasi terlihat dari kejujuran atau kedustaannya (Al-Ayyubi, 2018). Pemanfaatan media sosial secara umum maupun sebagai sarana berdakwah harus memperhatikan etika-etika dan norma-norma dalam bermedia sosial (Sumadi, 2016). Konsumsi hadis pada zaman modern sudah tidak terlalu memperhatikan keshahihan sebuah hadis, hal ini terlihat dari bagaimana narasi keagamaan digunakan untuk kepentingan tertentu (Saputra \& Suryadilaga, 2020). Termasuk hal yang sangat penting dalam memahami sunnah dengan baik, ialah dengan cara menyesuaikan antara berbagai hadis shahih yang redaksinya tampak seolah-olah bertentangan, demikian pula makna kandungannya, yang sepintas lalu tampak berbeda (alQardhawi, 1999). 
Berdasarkan paparan di atas, penelitian ini berusaha menyusun formula penelitian, yaitu rumusan, pertanyaan dan tujuan penelitian (Darmalaksana, 2020). Rumusan masalah penelitian ini adalah adanya bentuk konten hadis yang tersebar pada akun Lughoty.com, @RisalahMuslimID, dan @thesunnah_path tidak selalu memiliki kelengkapan struktur dalam sebuah hadis dan tidak selalu dinilai shahih. Pertanyaan dalam penelitian ini, yaitu: bagaimana fenomena dan keberadaan hadis di media sosial dalam jejaring sosial pada akun Lughoty.com, @RisalahMuslim, dan @thesunnah_path; dan bagaimana bentuk konten hadis dalam jejaring sosial Facebook, Twitter, dan Instagram pada akun Lughoty.com, @RisalahMuslimID, dan @thesunnah_path. Penelitian ini bertujuan untuk membahas konten hadis di media sosial dalam jejaring sosial Facebook, Twitter, dan Instagram dengan sampel akun Lughoty.com, @RisalahMuslimID, dan @thesunnah_path. Penelitian ini diharapkan dapat bermanfaat untuk kontribusi pengetahuan dan pemahaman dalam konten hadis yang diterima di media sosial dalam jejaring sosial Facebook, Twitter, dan Instagram.

\section{Metode Penelitian}

Penelitian ini merupakan jenis kualitatif yang melakukan analisis terhadap konten hadis dengan menggunakan analisis isi (content analysis), yakni penelitian yang bersifat pembahasan mendalam terhadap isi suatu informasi tertulis atau tercetak dalam media massa (Handoko, 2017). Tujuannya yaitu untuk menganalisis konten hadis di media sosial dalam jejaring sosial pada akun Lughoty.com, @RisalahMuslimID, dan @thesunnah_path.

Secara umum, terdapat dua tingkat dalam penelitian tentang hadis, yaitu takhrij dan syarah. Menurut Soetari yang dikutip oleh Darmalaksana, bahwa takhrij adalah proses mengeluarkan hadis dari kitab hadis untuk diteliti kesahihannya, sedang syarah ialah penjelasan teks hadis dengan analisis tertentu (Darmalaksana, 2020).

\section{Hasil dan Pembahasan}

Hasil penelitian dan pembahasan di bawah ini.

\section{Fenomena dan Eksistensi Hadis di Media Sosial}

Media sosial merupakan sebuah media online, di mana para penggunanya melalui aplikasi berbasis internet dapat berbagi, berpartisipasi, dan menciptakan konten berupa blog, wiki, forum, jejaring sosial, dan ruang dunia virtual yang disokong oleh teknologi multimedia yang kian canggih (Mulyati, 2014).

Media sosial mengubah cara informasi yang disampaikan ke seluruh masyarakat dan di seluruh dunia. Kecepatan dan transparansi informasi telah meningkat secara dramatis (Mayfield, 2008). Karena dari kemudahan 
penggunaan, kecepatan dan jangkauan, media sosial cepat mengubah wacana publik di masyarakat dan menetapkan tren dan agenda dalam topik yang berkisar dari lingkungan dan politik hingga teknologi dan industri hiburan (Asur \& Huberman, 2010).

Pada saat ini, jejaring sosial, blog, dan wiki merupakan media sosial yang paling banyak digunakan dan tumbuh pesat di antara yang lainnya (Mulyati, 2014). Salah satu fasilitas teknologi yang dijadikan sebagai "darah daging" masyarakat adalah situs jejaring sosial. Dalam praktik sehari-hari, layanan jejaring sosial semacam itu rutin diakses oleh ratusan ribu atau bahkan jutaan masyarakat pengguna internet dari seluruh dunia (Sosiawan, 2011).

Beragam aplikasi diciptakan untuk memenuhi kebutuhan sosialisasi manusia. Aplikasi-aplikasi jejaring sosial online diciptakan dengan mereplikasi pola jejaring di kehidupan nyata hanya saja dalam cakupan yang lebih luas. Lihat saja bagaimana Facebook, Twitter, Path, Instagram, MySpace, 4Shared, YouTube, dan lain sebagainya membuat manusia saling terhubung satu sama lain (Fahrimal, 2018).

Melalui aplikasi-aplikasi tersebut masyarakat pengguna internet dapat membuat konten dan membagikannya di media sosial. Sebagai pusat informasi dan dengan sifatnya yang terbuka, konten yang dibagikan di media sosial dengan mudahnya bisa menyebar ke berbagai penjuru dunia dengan cepat. Konten yang dibagikan bisa berupa informasi yang valid atau invalid (palsu). Transparansi informasi inilah yang perlu diteliti kembali kebenarannya, termasuk konten hadis.

Konten hadis yang tersebar di media sosial begitu banyak. Bahkan dalam setiap platform jejaring sosial yang ada di media sosial hampir semua memiliki konten yang terdapat hadis di dalamnya. Namun, tidak semua konten hadis yang tersebar di media sosial shahih kualitasnya. Hadis sendiri dipahami sebagai apapun yang berasal dari Nabi Saw. (Darmalaksana, 2004). Hadis diposisikan sebagai sumber kedua Islam setelah al-Qur'an (Darmalaksana, Pahala, \& Soetari, 2017). Berbeda dengan al-Qur'an yang mutawatir, sedangkan hadis bersifat relatif (Soetari, 1994). Sebab, hadis baru dibukukan pada abad ke-8 (Soetari, 1994). Sehingga kesahihan (otentisitas) hadis perlu dilakukan pengujian apakah benar dari Nabi Saw. ataukah dari selain Nabi Saw. (Darmalaksana, 2004).

Hadis telah disampaikan dan dibukukan sudah lama oleh Nabi Saw. sehingga dapat dikaji dan didiskusikan sampai saat ini. Namun sebuah persoalan, bahwa kondisi sosial masyarakat Islam dahulu dan sekarang memiliki perbedaan, yaitu semakin berkembang, sedangkan teks hadis tetap tanpa berubah sedikitpun. Berangkat dari hal tersebut menjadikan banyak ulama yang kemudian mulai mengupayakan kesesuaian makna hadis di zaman dahulu untuk ditarik dan diterapkan di zaman sekarang. Sejumlah ulama seperti mengupayakan pemahaman hadis tekstual dan 
kontekstual lokal, universal dan temporal (Ismail, 1994). Dalam periode abad ke-21 ini pemahaman hadis secara kontekstualisasi marak dilakukan, namun dengan semakin majunya perkembangan teknologi maka tidak dapat dipungkiri adanya sisi kekurangan, khususnya terkait dengan memahami hadis. Dengan adanya kebebasan dalam menyampaikan pikiran di media online, nampak semakin massifnya pemahaman hadis dilakukan (Syifana \& Pratama, 2021). Oleh karena itu, kesadaran bahwa pemahaman hadis dalam bentuk sebuah konten di media sosial telah berkembang dari teks ke konteks adalah sebuah keniscayaan seiring berkembangnya teknologi dan ilmu pengetahuan.

Konten hadis yang tersebar di media sosial tidak sepenuhnya bisa dijadikan dalil untuk menjalankan sunnah Rasul, kecuali jika kita sendiri yang mencari kebenaran atas kualitas hadis tersebut. Tidak sedikit kasus di media sosial yang memposting konten hadis, namun hadis tersebut setelah diteliti kembali ternyata hadis dha'if (palsu). Dampaknya, kita yang mengirimkan atau menerima informasi tersebut mendapatkan dan menyebarluaskan kesesatan kepada orang lain.

Pencarian informasi mengenai hadis pada masa perkembangan teknologi yang kian canggih, memudahkan para pengguna internet untuk mendapatkan hadis yang diinginkannya melalui aplikasi yang tersedia pada smartphone. Dari sekian banyaknya aplikasi jejaring sosial yang digunakan, penulis akan memaparkan aplikasi yang sering dan banyak digunakan oleh kalangan masyarakat saat ini, yaitu Facebook, Twitter, dan Instagram.

Pada jejaring sosial Facebook, pengguna dapat memasukkan kata kunci 'hadis' untuk mendapatkan informasi mengenai hadis. Hasilnya, banyak akun maupun postingan yang membahas tentang hadis. Tidak hanya berupa akun, namun juga terdapat halaman, grup, maupun acara online yang dihasilkan oleh sistem pencarian tersebut.

Gambar 1. Pencarian pada Facebook

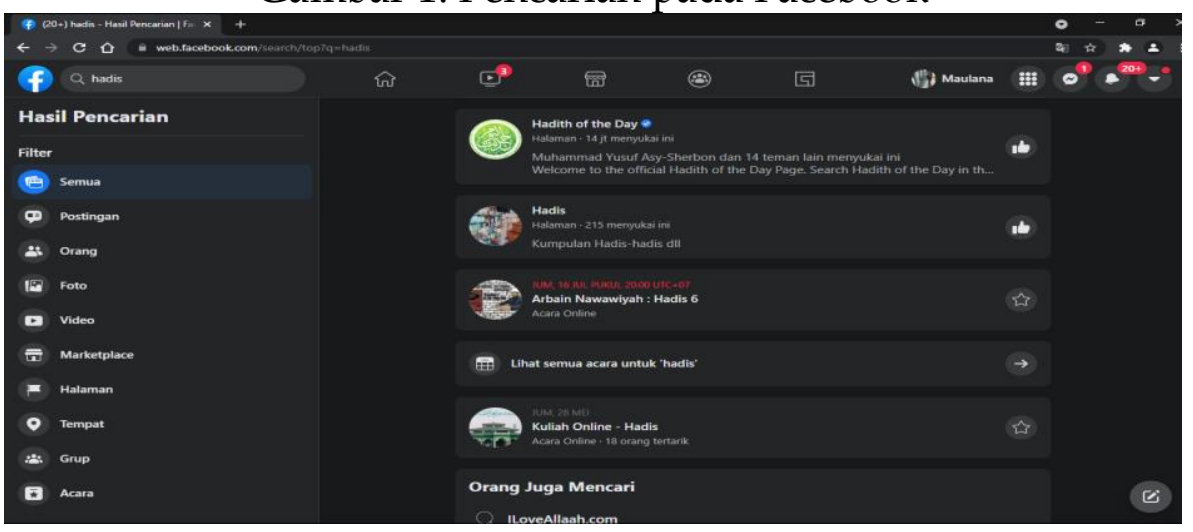


Gambar 1 merupakan hasil dari kolom pencarian melalui jejaring sosial Facebook dengan kata kunci ‘hadis'. Dari sekian banyaknya akun dan postingan yang dihasilkan, penulis meneliti satu akun berupa halaman yang bernama Lughoty.com karena halaman ini sering muncul dalam hasil pencarian. Semua itu karena halaman ini aktif dalam memposting konten setiap hari.

Sampai data dan artikel ini dibuat, pada tanggal 28 Juli 2021, halaman Lughoty.com ini memiliki 39 ribu lebih orang yang menyukai halaman ini dan 40 ribu lebih orang yang mengikuti halaman ini. Selain itu, halaman ini memiliki situs yaitu https://lughoty.com/. Pada salah satu konten hadis yang diposting oleh akun ini, terdapat 1.226 orang yang menyukai, 24 komentar, dan 201 kali postingan ini dibagikan kembali. Data ini bisa saja bertambah seiring berjalannya waktu.

Gambar 2. Bentuk Berbagi Konten Hadis

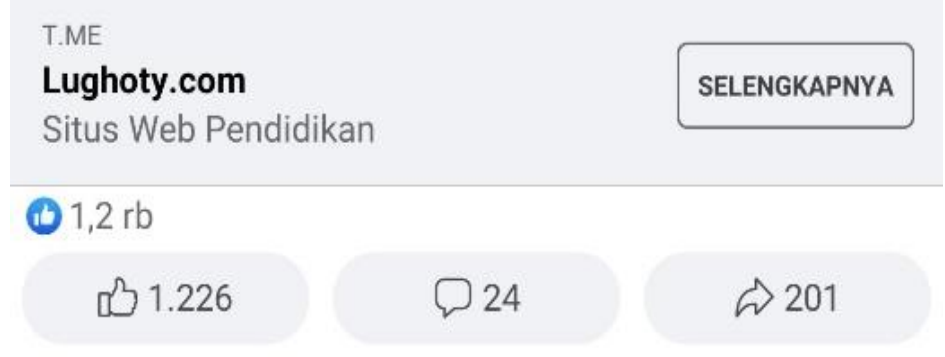

Gambar 2 merupakan data penyuka, komen, dan bagikan kembali pada salah satu konten hadis yang dibagikan oleh halaman Lughoty.com.

Kemudian pada jejaring sosial Twiter, pencarian konten hadis pada jejaring sosial ini penulis memasukkan kata kunci 'hadis' dan '\#hadis' pada kolom pencarian dengan memakai filter 'populer'. Hasilnya, terdapat banyak akun yang memposting konten hadis berupa foto, video ataupun hanya sebuah teks.

Gambar 3. Pencarian pada Twitter

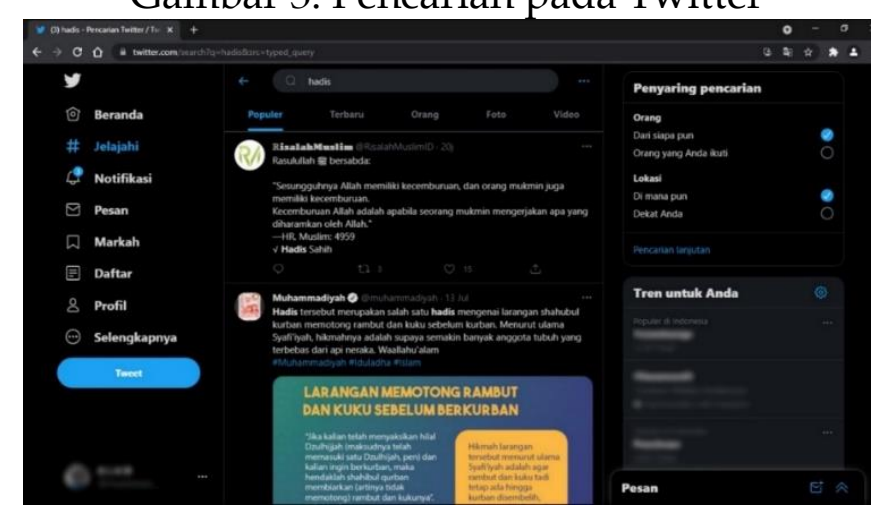


Gambar 3 menunjukkan hasil pencarian terkait konten hadis. Dari sekian banyaknya postingan yang ada dalam pencarian di Twitter, penulis meneliti sebuah akun yang bernama Risalah Muslim dengan username @RisalahMuslimID karena akun ini sering muncul dalam hasil pencarian. Akun ini memiliki 9.400 pengikut lebih dengan 84 ribu tweet sampai data ini diambil. Selain itu, akun ini memiliki situs yaitu risalahmuslim.id.

Selanjutnya pencarian konten hadis dalam jejaring sosial Instagram penulis menggunakan kata kunci '\#hadis' pada kolom pencarian. Terdapat setidaknya 2,5 juta postingan yang dihasilkan dengan menggunakan kata kunci tersebut. Dari hasil tersebut terdapat postingan foto maupun video. Namun hasilnya kebanyakan menggunakan bahasa asing selain bahasa Indonesia.

\section{Gambar 4. Pencarian pada Instagram}

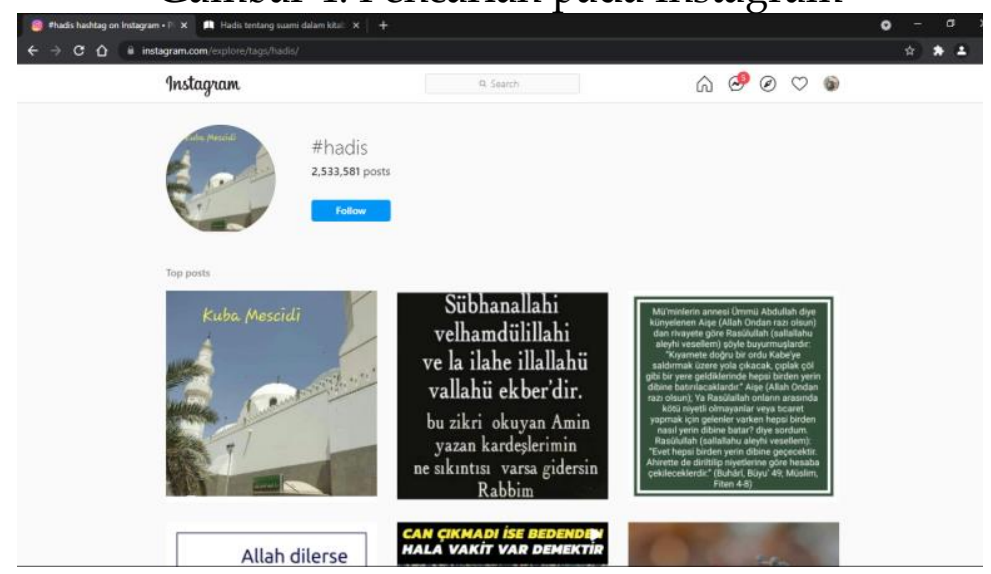

Gambar 4 menunjukkan hasil pencarian terkait konten hadis. Setelah penelusuran lebih dalam, penulis menemukan sebuah akun yang bernama Wadah Media Dakwah Sunnah dengan nama pengguna @thesunnah_path. Sejauh data yang diambil sampai saat ini, akun tersebut memiliki 9,2 ribu lebih postingan, 721 ribu pengikut, dan 320 mengikuti.

Pada salah satu konten hadis yang dibagikan oleh akun ini terdapat lebih dari 20 ribu menyukai dan 221 komentar pada postingan ini. Dalam kolom komentar banyak pengguna internet yang menanyakan perihal konten hadis yang dibagikan. Dengan adanya fitur 'balas komen' pada Instagram, pengguna internet lainnya pun ikut membantu menjawab dengan menyematkan sumbernya juga. 
Gambar 5. Data Berbagi Konten Hadis

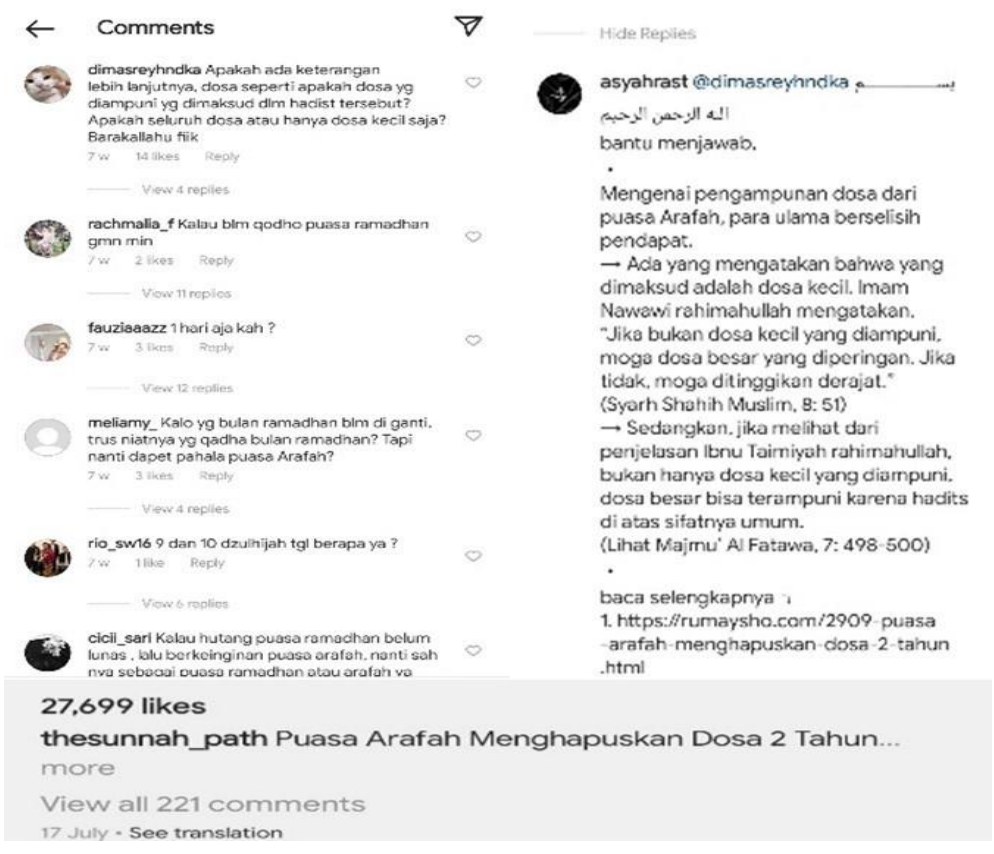

Gambar 5 menunjukkan pada salah satu konten hadis yang dibagikan oleh akun @thesunnah_path memiliki lebih dari 20 ribu penyuka, beserta komentar yang terdapat di dalamnya pengguna internet lain yang bertanya perihal konten hadis yang dibagikan, berikut juga ada pula yang membantu menjawab dalam komentar dengan menyebutkan sumber juga.

\section{Bentuk Konten Hadis di Jejaring Sosial}

Jejaring sosial adalah salah satu media sosial yang banyak digunakan masyarakat pengguna internet saat ini. Jejaring sosial merupakan struktur sosial yang terdiri dari elemen-elemen individual atau organisasi. Jejaring ini menunjukkan jalan dimana mereka berhubungan karena kesamaan sosialitas, mulai dari mereka yang dikenal sehari-hari sampai dengan keluarganya (Yusrintosepu, 2018).

Jejaring sosial merupakan sebuah bentuk layanan internet yang bisa berupa website maupun aplikasi. Berikut adalah bentuk konten hadis dalam jejaring sosial pada akun Lughoty.com, @RisalahMuslimID, dan @thesunnah_path.

\section{a) Lughoty.com (Facebook)}

Facebook adalah sebuah layanan jejaring sosial yang diluncurkan pada bulan Februari 2004 oleh seseorang bernama Mark Zuckerberg. Facebook merupakan salah satu jejaring sosial di media sosial yang banyak digunakan oleh pengguna internet. Per September 2012, Facebook memiliki lebih dari satu miliar pengguna aktif. 
Pada jejaring sosial Facebook ini, penulis meneliti sebuah halaman @Lughoty.com. Halaman ini kerap membagikan konten-konten Islam berupa potongan ayat dalam surah al-Qur'an, sabda Nabi Saw. (hadis), microblog, maupun kutipan dalam sebuah kitab. Konten-konten yang dibagikan oleh halaman ini, memiliki desain yang unik serta menarik. Tentu saja desain adalah salah satu pengaruh agar orang-orang tertarik untuk melihat, membaca lalu membagikannya kembali. Selain membagikan konten berupa desain grafis dengan isinya adalah hadis, pembuat halaman ini juga memberikan keterangan pada kontennya.

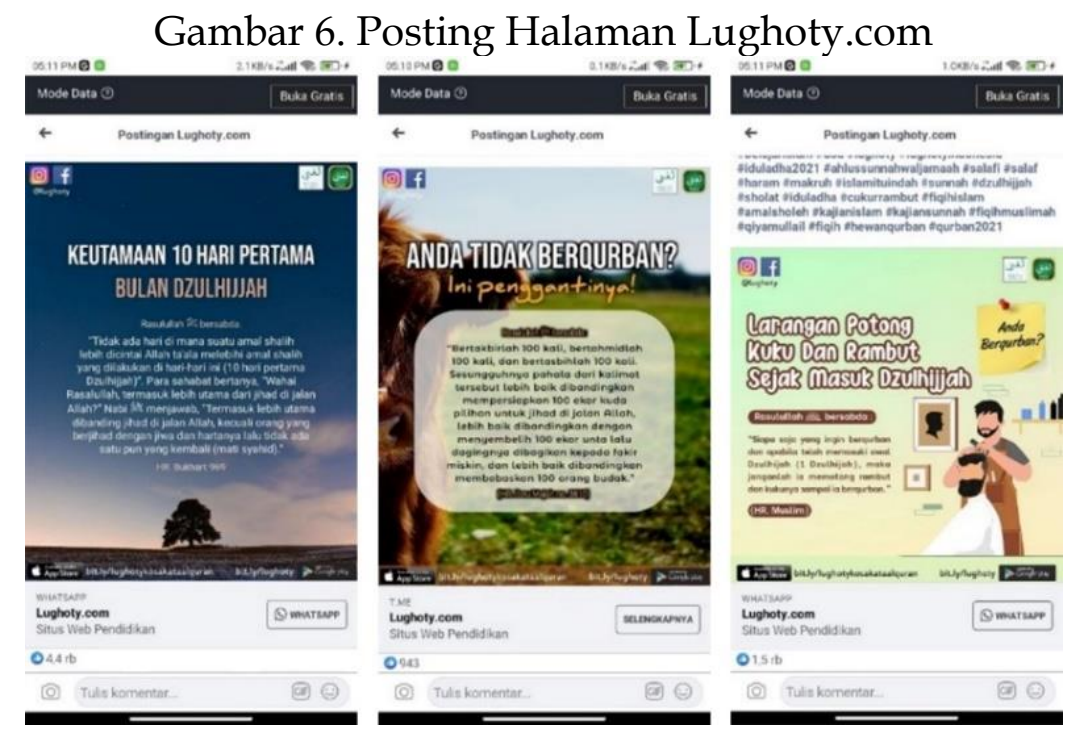

Gambar 6 mendeskripsikan postingan yang dibagikan oleh pemilik halaman Lughoty.com dengan sebuah foto dan desain grafis yang berupa teks tekait hadis di dalamnya.

Kemudian penulis mengambil sampel konten hadis dalam postingan satu bulan terakhir terhitung dari 28 Juni 2021 sampai 28 Juli 2021, yaitu berjumlah 24 konten hadis yang dibagikan oleh halaman Lughoty.com. Sampel ini ditentukan dengan menggunakan teknik proporsional random sampling. Kemudian berdasarkan teori yang diungkapkan oleh Arikunto yang dikutip oleh Reni Ferlitasari, bahwa untuk sekedar kira-kira maka apabila objeknya kurang dari 100, lebih baik seluruh populasi dijadikan sebagai sampel, sehingga penelitiannya dijadikan penelitian populasi, selanjutnya apabila jumlah objeknya yang akan diteliti lebih dari 100 maka akan diambil sebagai sampel antara 10-15\%, 20-25\% atau lebih (Ferlitasari, 2018).

Dari pernyataan sebelumnya menunjukkan bahwa sampel yang diambil pada halaman Lughoty.com berjumlah 24 postingan konten hadis yang bisa dilihat dalam tabel berikut: 
Tabel 1.1. Sampel Hadis pada Akun Lughoty.com

\begin{tabular}{|c|c|c|c|}
\hline Hadis & $\begin{array}{l}\text { Hadis Riwayat } \\
\text { - Nomor Hadis }\end{array}$ & Isi & $\begin{array}{l}\text { Penilaian } \\
\text { Ulama }(*)\end{array}$ \\
\hline 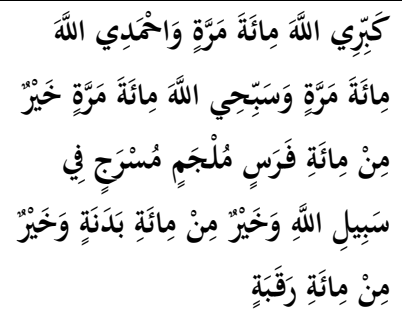 & $\begin{array}{l}\text { Ibnu Majah - } \\
3800\end{array}$ & $\begin{array}{l}\text { Keutamaan } \\
\text { tasbih }\end{array}$ & $\begin{array}{l}\text { Hasan } \\
\text { menurut } \\
\text { Muhammad } \\
\text { Nashiruddin } \\
\text { al-Albani }\end{array}$ \\
\hline 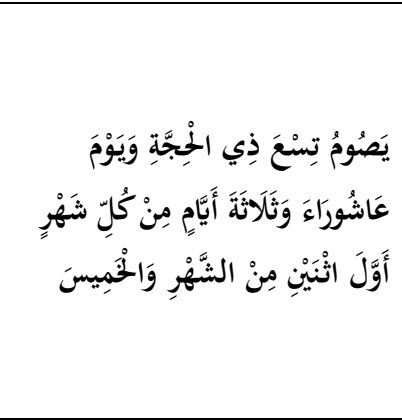 & $\begin{array}{l}\text { Abu Daud - } \\
2081\end{array}$ & $\begin{array}{l}\text { Puasa } \\
\text { sepuluh hari } \\
\text { (bulan } \\
\text { Dzulhijjah) }\end{array}$ & $\begin{array}{l}\text { Shahih } \\
\text { menurut } \\
\text { Muhammad } \\
\text { Nashiruddin } \\
\text { al-Albani; } \\
\text { Dha'if } \\
\text { menurut Ibnu } \\
\text { al-Turkumani }\end{array}$ \\
\hline 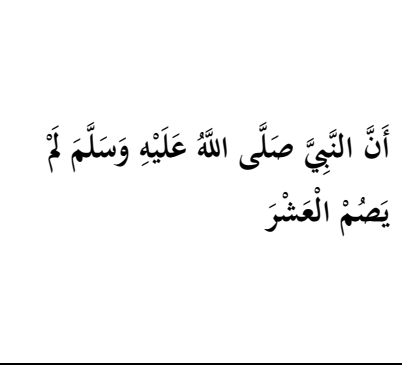 & Muslim - 2011 & $\begin{array}{l}\text { Nabi Saw. } \\
\text { tidak pernah } \\
\text { berpuasa } \\
\text { pada sepuluh } \\
\text { hari pertama } \\
\text { dari bulan } \\
\text { Dzulhijjah } \\
\end{array}$ & $\begin{array}{l}\text { Shahih } \\
\text { menurut Ijma' } \\
\text { Ulama }\left(^{* *}\right)\end{array}$ \\
\hline 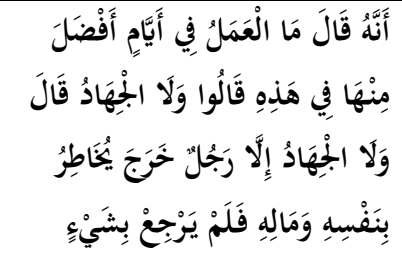 & Bukhari - 916 & $\begin{array}{l}\text { Keutamaan } \\
\text { beramal pada } \\
\text { hari-hari } \\
\text { tasyriq }\end{array}$ & $\begin{array}{l}\text { Shahih } \\
\text { menurut Ijma' } \\
\left.\text { Ulama }{ }^{* *}\right)\end{array}$ \\
\hline 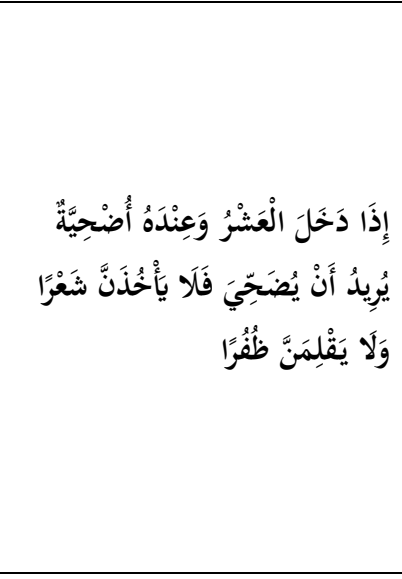 & Muslim - 3654 & \begin{tabular}{|l} 
Larangan \\
mencukur \\
rambut atau \\
memotong \\
kuku saat \\
masuk \\
sepuluh hari \\
di bulan \\
Dzulhijjah \\
dan akan \\
berkurban \\
\end{tabular} & $\begin{array}{l}\text { Shahih } \\
\text { menurut Ijma' } \\
\left.\text { Ulama }{ }^{(*)}\right)\end{array}$ \\
\hline
\end{tabular}




\begin{tabular}{|c|c|c|c|}
\hline 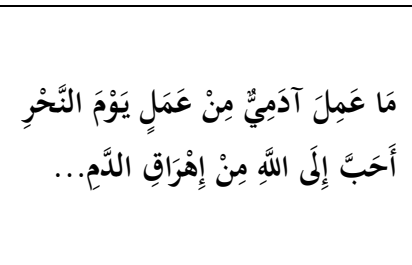 & Tirmidzi - 1413 & $\begin{array}{l}\text { Keutamaan } \\
\text { sembelihan }\end{array}$ & $\begin{array}{l}\text { Dha'if } \\
\text { menurut } \\
\text { Muhammad } \\
\text { Nashiruddin } \\
\text { al-Albani }\end{array}$ \\
\hline 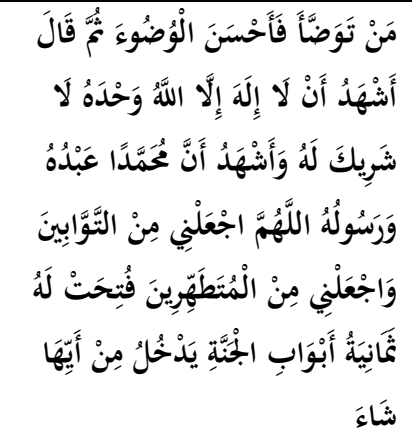 & Nasa'i - 148 & $\begin{array}{l}\text { Do'a selesai } \\
\text { wudlu }\end{array}$ & $\begin{array}{l}\text { Shahih } \\
\text { menurut } \\
\text { Muhammad } \\
\text { Nashiruddin } \\
\text { al-Albani }\end{array}$ \\
\hline 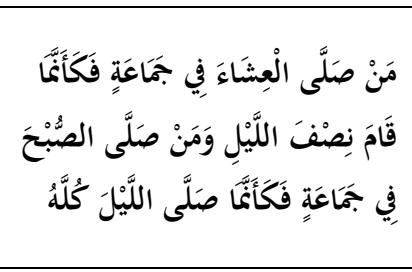 & Muslim - 1049 & $\begin{array}{l}\text { Keutamaan } \\
\text { shalat Isya' } \\
\text { dan Shubuh } \\
\text { secara } \\
\text { berjamaah } \\
\end{array}$ & $\begin{array}{l}\text { Shahih } \\
\text { menurut Ijma' } \\
\text { Ulama }\left(^{* *}\right)\end{array}$ \\
\hline 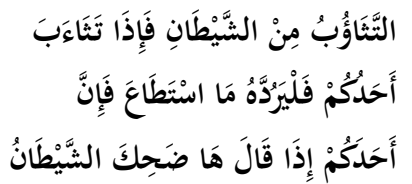 & Bukhari - 3046 & $\begin{array}{l}\text { Menutup } \\
\text { mulut saat } \\
\text { menguap }\end{array}$ & $\begin{array}{l}\text { Shahih } \\
\text { menurut Ijma' } \\
\text { Ulama }\left(^{* *}\right)\end{array}$ \\
\hline 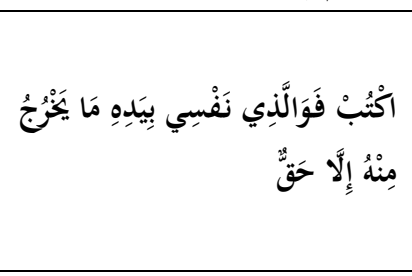 & $\begin{array}{l}\text { Abu Daud - } \\
3161\end{array}$ & $\begin{array}{l}\text { Menulis } \\
\text { tentang } \\
\text { kebenaran }\end{array}$ & $\begin{array}{l}\text { Shahih } \\
\text { menurut } \\
\text { Muhammad } \\
\text { Nashiruddin } \\
\text { al-Albani }\end{array}$ \\
\hline 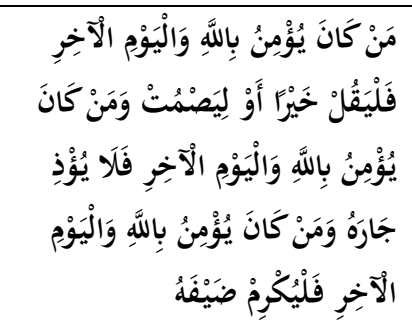 & Bukhari - 5994 & Menjaga lisan & $\begin{array}{l}\text { Shahih } \\
\text { menurut Ijma' } \\
\text { Ulama }\left(^{* *}\right)\end{array}$ \\
\hline 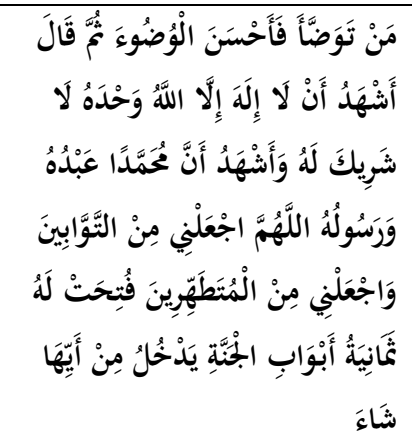 & Tirmidzi - 50 & $\begin{array}{l}\text { Ganjaran } \\
\text { membaca } \\
\text { do'a setelah } \\
\text { wudlu }\end{array}$ & $\begin{array}{l}\text { Shahih } \\
\text { menurut } \\
\text { Muhammad } \\
\text { Nashiruddin } \\
\text { al-Albani }\end{array}$ \\
\hline
\end{tabular}




\begin{tabular}{|c|c|c|c|}
\hline 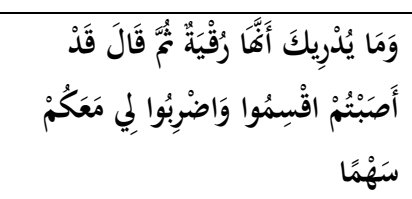 & Bukhari - 2115 & $\begin{array}{l}\text { Di antara } \\
\text { khasiat surat } \\
\text { al-Fatihah }\end{array}$ & $\begin{array}{l}\text { Shahih } \\
\text { menurut Ijma' } \\
\text { Ulama }\left({ }^{* *}\right)\end{array}$ \\
\hline 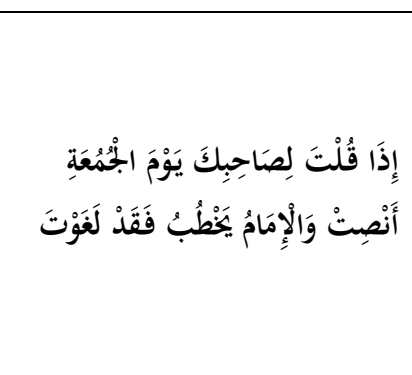 & Bukhari - 882 & $\begin{array}{l}\text { Tidak } \\
\text { mendapat } \\
\text { pahala orang } \\
\text { yang } \\
\text { berbicara saat } \\
\text { khutbah } \\
\text { Jum'at }\end{array}$ & $\begin{array}{l}\text { Shahih } \\
\text { menurut Ijma' } \\
\text { Ulama }\left({ }^{* *}\right)\end{array}$ \\
\hline 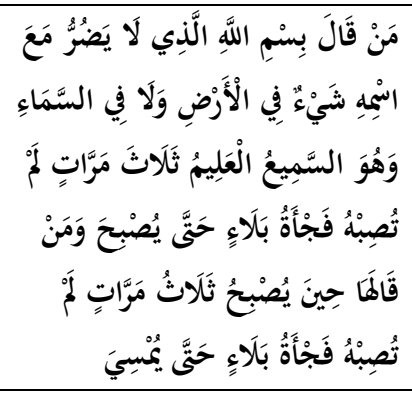 & $\begin{array}{l}\text { Abu Daud - } \\
4425\end{array}$ & $\begin{array}{l}\text { Do'a saat } \\
\text { bangun pagi }\end{array}$ & $\begin{array}{l}\text { Shahih } \\
\text { menurut } \\
\text { Muhammad } \\
\text { Nashiruddin } \\
\text { al-Albani }\end{array}$ \\
\hline 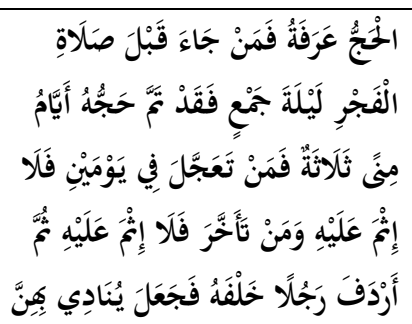 & $\begin{array}{l}\text { Ibnu Majah - } \\
3006\end{array}$ & $\begin{array}{l}\text { Cara } \\
\text { melaksanaka } \\
\text { n haji }\end{array}$ & $\begin{array}{l}\text { Shahih } \\
\text { menurut } \\
\text { Muhammad } \\
\text { Nashiruddin } \\
\text { al-Albani }\end{array}$ \\
\hline 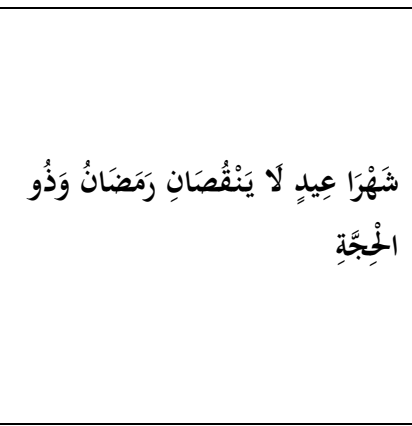 & Muslim - 1882 & $\begin{array}{l}\text { Tidak akan } \\
\text { berkurang } \\
\text { pahala pada } \\
\text { dua bulan } \\
\text { hari raya } \\
\text { (Ramadhan } \\
\text { dan } \\
\text { Dzulhijjah) }\end{array}$ & $\begin{array}{l}\text { Shahih } \\
\text { menurut Ijma' } \\
\text { Ulama }\left({ }^{* *}\right)\end{array}$ \\
\hline 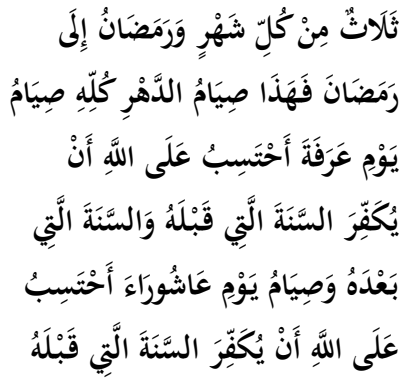 & Muslim - 1976 & $\begin{array}{l}\text { Anjuran } \\
\text { puasa pada } \\
\text { hari 'Arafah }\end{array}$ & $\begin{array}{l}\text { Shahih } \\
\text { menurut Ijma' } \\
\text { Ulama }\left({ }^{* *}\right)\end{array}$ \\
\hline
\end{tabular}




\begin{tabular}{|c|c|c|c|}
\hline 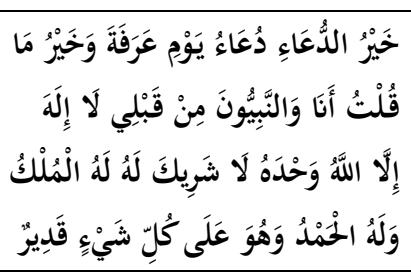 & Tirmidzi - 3509 & $\begin{array}{l}\text { Do'a pada } \\
\text { hari 'Arafah }\end{array}$ & \begin{tabular}{|l} 
Hasan \\
menurut \\
Muhammad \\
Nashiruddin \\
al-Albani \\
\end{tabular} \\
\hline 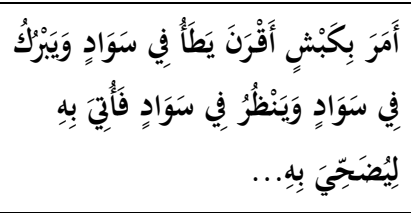 & Muslim - 3767 & $\begin{array}{l}\text { Do'a } \\
\text { menyembelih } \\
\text { hewan } \\
\text { kurban }\end{array}$ & $\begin{array}{l}\text { Shahih } \\
\text { menurut Ijma' } \\
\text { Ulama }\left({ }^{* *}\right)\end{array}$ \\
\hline 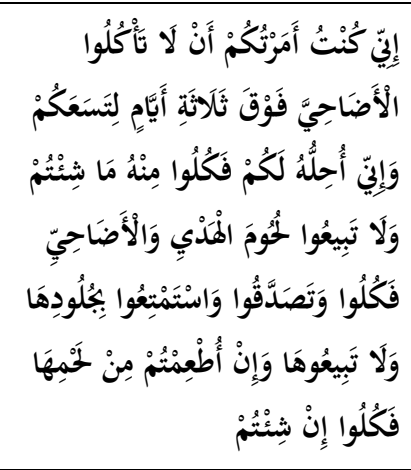 & Ahmad - 15622 & $\begin{array}{l}\text { Larangan } \\
\text { menjual } \\
\text { daging hadyu } \\
\text { (daging yang } \\
\text { disembelih } \\
\text { Jamaah Haji } \\
\text { waktu } \\
\text { pelaksanaan } \\
\text { ibadah) }\end{array}$ & $\begin{array}{l}\text { Isnad dha'if } \\
\text { menurut } \\
\text { Syu'aib al- } \\
\text { Arna'uth }\end{array}$ \\
\hline 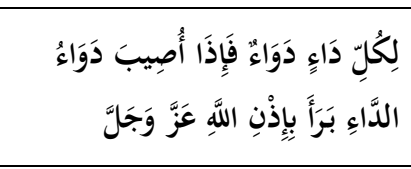 & Muslim - 4084 & $\begin{array}{l}\text { Setiap } \\
\text { penyakit ada } \\
\text { obatnya }\end{array}$ & $\begin{array}{l}\text { Shahih } \\
\text { menurut Ijma' } \\
\text { Ulama }\left(^{* *}\right)\end{array}$ \\
\hline 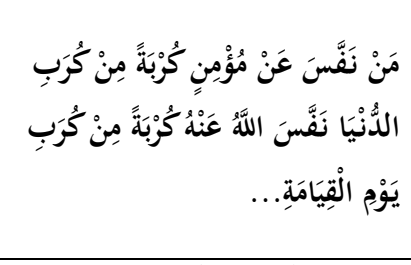 & Muslim - 4867 & $\begin{array}{l}\text { Ganjaran } \\
\text { meringankan } \\
\text { kesulitan } \\
\text { sesama } \\
\text { muslim } \\
\end{array}$ & $\begin{array}{l}\text { Shahih } \\
\text { menurut Ijma' } \\
\text { Ulama }\left(^{* *}\right)\end{array}$ \\
\hline 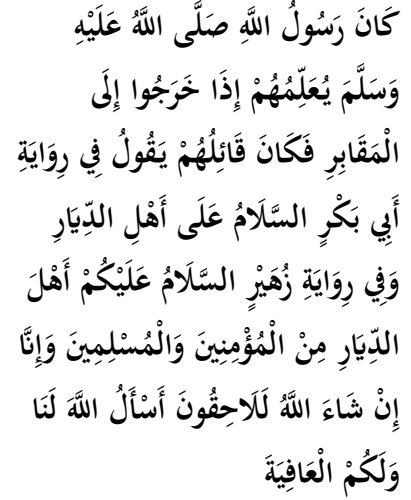 & Muslim - 1620 & $\begin{array}{l}\text { Do'a saat } \\
\text { masuk } \\
\text { kuburan }\end{array}$ & $\begin{array}{l}\text { Shahih } \\
\text { menurut Ijma' } \\
\text { Ulama }\left({ }^{* *}\right)\end{array}$ \\
\hline
\end{tabular}

(*) Penlilaian Ulama $=$ menurut aplikasi 'Ensiklopedi Hadits 9 Imam' (Android).

(**) Ijma' Ulama = Menurut Abdul Karim Zaidan, adalah kesepakatan para ulama mujtahid dari kalangan umat Islam (AS, 2014).

Tabel 1.1 menunjukkan dua puluh empat sampel konten hadis yang dibagikan, penulis meneliti kembali hadis yang terdapat pada kontenkonten tersebut. Hasilnya seperti yang terdapat pada tabel di atas, bahwa 
akun ini tidak selalu memposting konten hadis dengan kualitas shahih, bahkan tiga di antaranya dinilai dha'if dan dua lainnya dinilai hasan. Walaupun tidak mencantumkan sanad maupun teks hadis aslinya, halaman ini memberi keterangan mukharrij (orang yang mengeluarkan hadis) dan nomor hadis di kolom caption dari konten hadis tersebut. Lebih lanjut, dalam kolom komentar terdapat beberapa akun yang bertanya mengenai kontennya. Pembuat halaman ini tentu membalasnya dengan referensi dari sumber yang terpercaya. Satu di antara sepuluh konten hadis yang dibagikan, penulis menemukan hadis yang terdapat kekeliruan dalam pemahaman hadis sebagaimana yang terdapat pada postingan seperti pada Gambar 7.

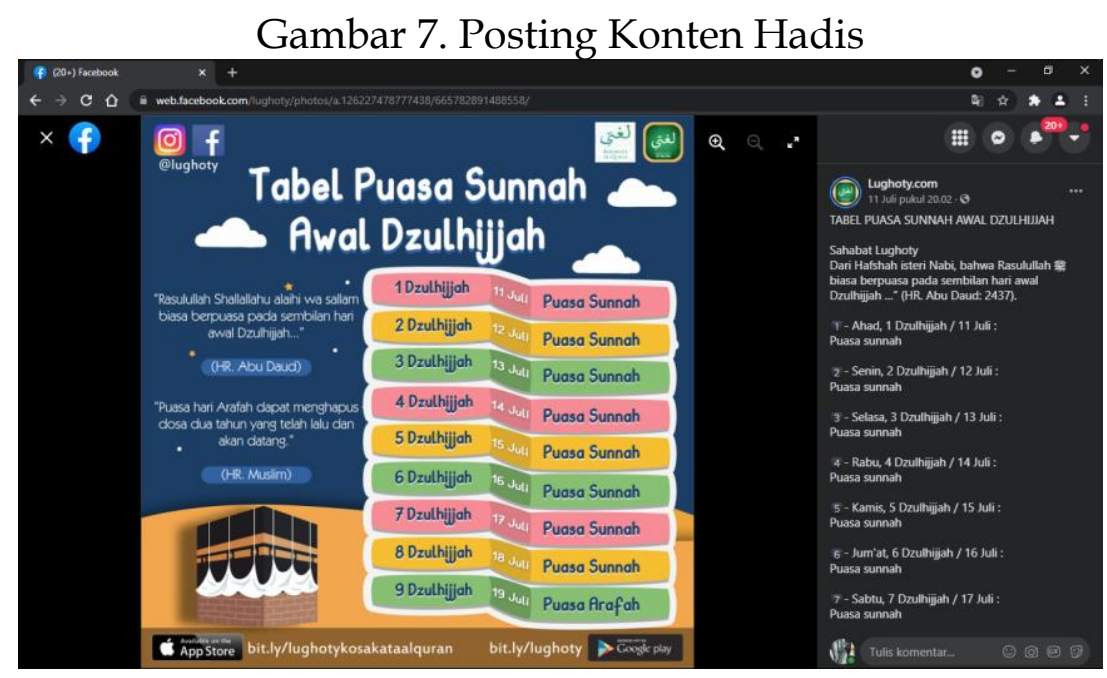

Gambar 7 mendeskripsikan postingan konten hadis yang terdapat kekeliruan dalam pemahaman hadis. Adapun teks asli dari hadis tersebut, yaitu:

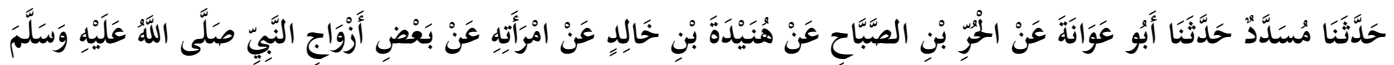

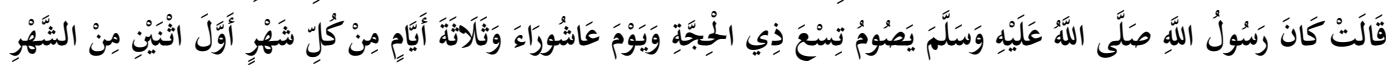

Sunan Abu Daud No. 2081: Telah menceritakan kepada kami [Musaddad], telah menceritakan kepada kami [Abu 'Awanah] dari [al-Hurr bin Ash Shabbah], dari [Hunaidah bin Khalid] dari [Seorang wanita] dari [sebagian isteri Nabi shallallahu 'alaihi wasallam] ia berkata; Rasulullah shallallahu 'alaihi wasallam berpuasa pada tanggal sembilan Bulan Dzul Hijjah, serta pada Hari 'Asyura' serta tiga hari dari setiap bulan, dan hari Senin serta Kamis pada setiap bulan (Daud). 
Meskipun konten hadis di atas terdapat dua hadis yang terlihat saling menguatkan, namun tidak ada hubungannya sama sekali. Setelah diteliti lebih dalam ternyata ada kekeliruan dalam pemahaman hadis mengenai 9 Dzulhijjah. Yang mana sebagian dari mereka memahami bahwasannya 9 Dzulhijjah itu diartikan sebagai jumlah hari, dari 1 Dzulhijjah sampai 9 Dzulhijjah. Mengenai hadis tersebut atau pemahaman tersebut, bertentangan dengan hadis riwayat Muslim yang diterima dari 'Aisyah:

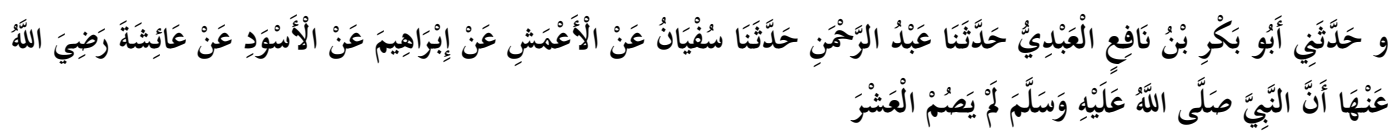

Shahih Muslim No. 2011: Dan telah menceritakan kepadaku [Abu Bakr bin Nafi' al-Abdi] telah menceritakan kepada kami [Abdurrahman] telah menceritakan kepada kami [Sufyan] dari [al-A'masy] dari [Ibrahim] dari [al-Aswad] dari [Aisyah] radliallahu 'anha, bahwa Nabi shallallahu 'alaihi wasallam Rasulullah shallallahu 'alaihi wasallam tidak pernah berpuasa pada sepuluh hari pertama dari bulan Dzul Hijjah (Muslim).

Adapun hadis yang diriwayatkan oleh Abu Daud tidak memiliki kejelasan siapa yang mendengar Rasul melakukan puasa selama sembilan hari karena di dalam periwayatannya itu rawi Hunaidah dan al-Hurr mengungkapkan dengan lafadz yang tidak jelas siapa yang mendengar Rasul atau melihat Rasul melakukan puasa sembilan hari. Hadis yang berada di dalam konten tersebut diriwayatkan oleh rawi yang hafalannya kacau atau idhtirab. Kemudian Ibnu Hibban menempatkan rawi Hunaidah ini ke dalam kitab Himpunan Hadis-Hadis Palsu (Hibban, 1973). Namun pada hadis yang diriwayatkan oleh Muslim memiliki kejelasan siapa yang mendengar atau melihat bahwa Rasulullah tidak pernah puasa selama sepuluh hari pada bulan Dzulhijjah dan tidak ada juga dalil pendamping yang menyebutkan bahwa 9 Dzulhijjah itu adalah sembilan hari. Oleh karena itu, hadis yang diriwayatkan Abu Daud yang menyatakan bahwa Rasul puasa pada sepuluh hari pertama di bulan Dzulhijjah itu dinilai dha' if karena ketidakjelasan rawi menerima periwatan dari siapa sekaligus juga bertentangan dengan hadis riawayat Muslim dari 'Aisyah yang menyatakan ia tidak pernah melihat Rasul melakukan puasa pada sepuluh hari pertama di bulan Dzulhijjah.

Dengan hasil penelitian yang telah dipaparkan dari akun halaman Lughoty.com, penulis menemukan kelebihan dan kekurangan dari halaman tersebut. Kelebihan pada halaman ini, yaitu membagikan sebuah konten dengan desain grafis yang unik dan menarik. Dengan begitu membuat para pembaca terpikat akan konten yang dibagikan lalu membuat pembaca tertarik untuk membacanya. Di samping itu, halaman 
ini tidak hanya membagikan konten hadis saja, melainkan konten-konten Islam lainnya, seperti potongan ayat dalam surah al-Qur'an maupun kutipan dalam sebuah kitab. Lalu dalam sebuah postingannya, halaman ini selalu memberikan penjelasan lebih lanjut pada kolom caption. Ditambah lagi bila ada yang bertanya pada kolom komentar, pemilik halaman ini mejawab secara jelas dengan mencantumkan sumber juga.

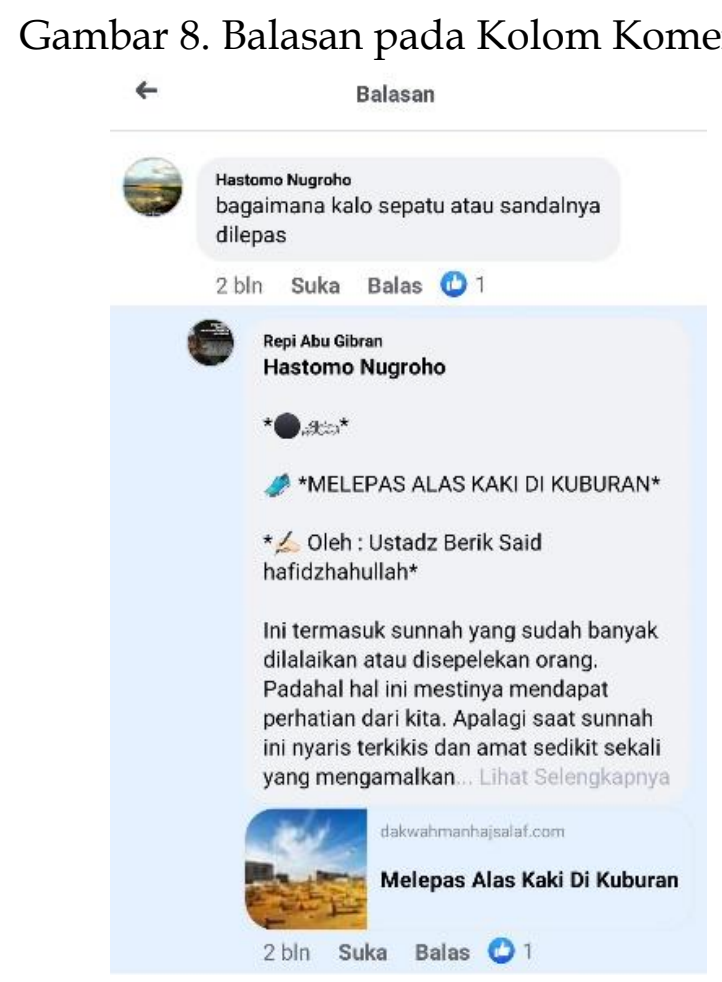

Gambar 8 mendeskripsikan bahwa pengguna internet yang bertanya pada kolom komentar akan dibalas oleh pemilik halaman dengan mencantumkan sumber.

Adapun kekurangan konten hadis yang dibagikan pada halaman ini, yaitu tidak mencantumkan teks asli dari hadis, begitu pun sanad dari rawi siapa hadis tersebut diambil. Kemudian juga tidak mencantumkan kualitas hadis sehingga perlu diteliti kembali kebenaran atas hadis tersebut untuk mengetahui kualitas dari sebuah hadis. Meskipun membagikan konten hadis yang rata-rata dinilai shahih ataupun hasan, akan tetapi penulis menemukan hadis yang terdapat kekeliruan dalam pemahaman hadis yang terdapat hadis dha' if pada konten-konten hadis di dalamnya.

\section{b)@RisalahMuslimID (Twitter)}

Twitter adalah sebuah layanan jejaring sosial untuk berkomunikasi dan tetap terhubung melalui pertukaran pesan yang cepat dan sering. 
Pendiri dari jejaring sosial Twitter adalah Jack Dorsey. Twitter sendiri didirikan pada 21 Maret 2006. Twitter juga merupakan jejaring sosial di media sosial yang sering digunakan dan memiliki miliaran pengguna aktif. Pengguna dapat memposting (tweet), yang dapat berisi foto, video, tautan, dan teks.

Pada jejaring sosial Twitter ini, penulis meneliti sebuah akun yang bernama Risalah Muslim dengan username @RisalahMuslimID. Akun ini memiliki 9.400 pengikut lebih dengan 84 ribu tweet sampai data ini diambil. Selain itu, akun ini memiliki situs yaitu risalahmuslim.id.

Profil akun ini membagikan konten Islam berupa potongan ayat dari surah al-Qur'an, sabda Nabi Saw. (hadis), sya'ir, maupun kutipan dari sahabat Nabi dan ulama terkemuka yang diambil dari sebuah kitab. Konten-konten hadis yang dibagikan dalam akun ini seringkali menggunakan desain grafis yang cukup simpel namun tetap menarik. Sebagian lainnya hanya berupa teks yang mencantumkan teks Arab, matan, terjemah, mukharrij, nomor hadis, serta kualitas dari hadis tersebut dan beberapa tanpa mencantumkan sanadnya. Namun, tidak semua hadis yang dibagikan oleh pembuat konten lengkap struktur hadisnya.

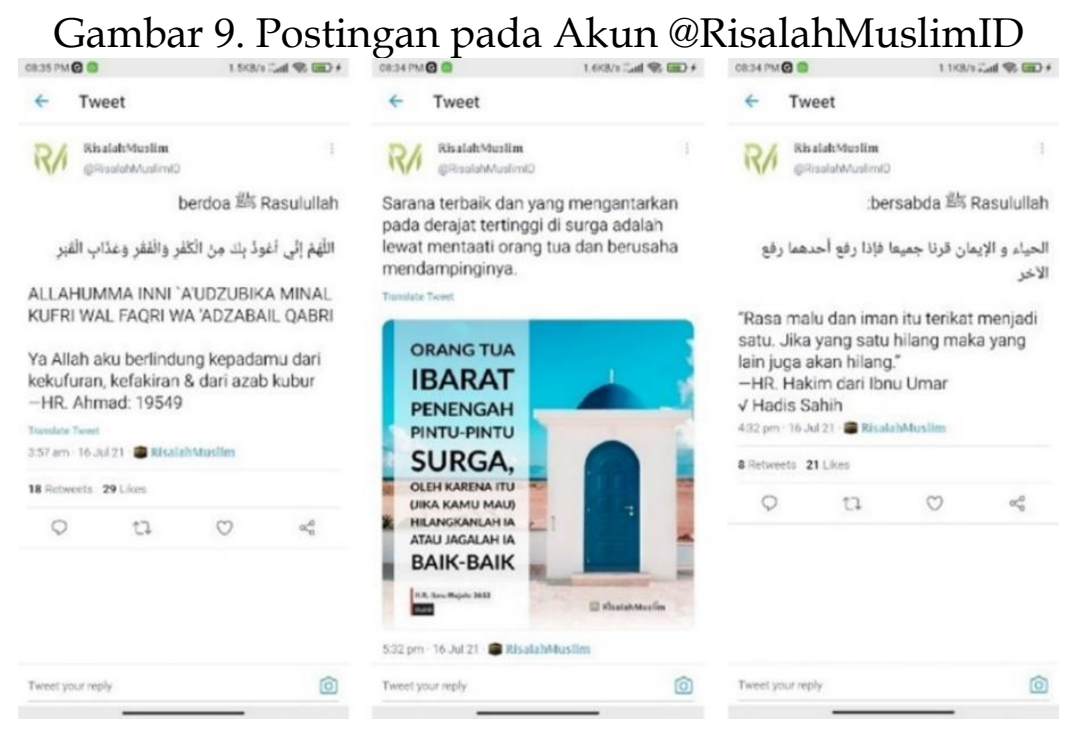

Gambar 9 mendeskripsikan postingan yang dibagikan oleh akun @RisalahMuslimID dengan sebuah desain grafis dan teks terkait hadis di dalamnya. Kemudian penulis mengambil sampel konten hadis dalam satu bulan terakhir yaitu berjumlah 150 postingan. Dengan teknik proporsional random sampling yang diungkapkan oleh Arikunto sebelumnya, maka penulis mengambil 10\% dari jumlah postingan yakni 15 postingan konten hadis yang bisa dilihat dalam tabel berikut: 
Tabel 1.2. Sampel Hadis pada Akun @RisalahMuslimID

\begin{tabular}{|c|c|c|c|}
\hline Hadis & $\begin{array}{l}\text { Hadis Riwayat } \\
\text { - Nomor Hadis }\end{array}$ & Isi & $\begin{array}{l}\text { Penilaian } \\
\text { Ulama }\left({ }^{*}\right)\end{array}$ \\
\hline 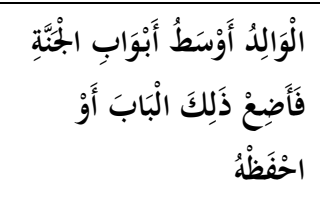 & $\begin{array}{l}\text { Ibnu Majah - } \\
5653\end{array}$ & $\begin{array}{l}\text { Berbakti kepada } \\
\text { kedua orang tua }\end{array}$ & $\begin{array}{l}\text { Shahih menurut } \\
\text { Muhammad } \\
\text { Nashiruddin al- } \\
\text { Albani }\end{array}$ \\
\hline 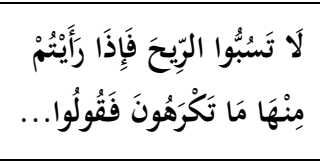 & Ahmad - 20214 & $\begin{array}{l}\text { Larangan } \\
\text { mencela angin }\end{array}$ & $\begin{array}{l}\text { Shahih menurut } \\
\text { Syu'aib al- } \\
\text { Arna'uth }\end{array}$ \\
\hline 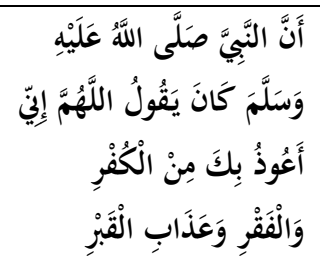 & Ahmad - 19487 & $\begin{array}{l}\text { Do'a berlindung } \\
\text { dari kekufuran, } \\
\text { kefakiran, dan } \\
\text { azab kubur }\end{array}$ & $\begin{array}{l}\text { Hasan menurut } \\
\text { Syu'aib al- } \\
\text { Arna'uth }\end{array}$ \\
\hline 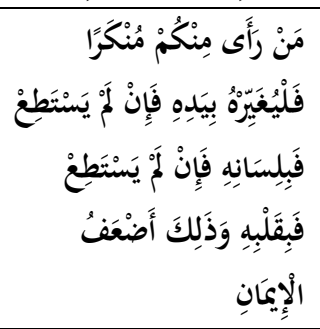 & Muslim - 70 & $\begin{array}{l}\text { Penjelasan } \\
\text { bahwa } \\
\text { mencegah } \\
\text { kemungkaran } \\
\text { adalah bagian } \\
\text { dari iman }\end{array}$ & $\begin{array}{l}\text { Shahih menurut } \\
\text { Ijma' Ulama }\left({ }^{* *}\right)\end{array}$ \\
\hline 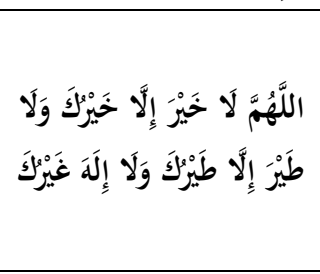 & Ahmad - 6748 & $\begin{array}{l}\text { Do'a memohon } \\
\text { kebaikan dan } \\
\text { nasib yang baik } \\
\text { datang dari } \\
\text { Allah }\end{array}$ & $\begin{array}{l}\text { Hasan menurut } \\
\text { Syu'aib al- } \\
\text { Arna'uth }\end{array}$ \\
\hline 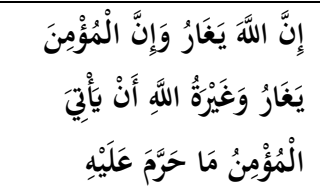 & Muslim - 4959 & $\begin{array}{l}\text { Kecemburuan } \\
\text { Allah }\end{array}$ & $\begin{array}{l}\text { Shahih menurut } \\
\text { Ijma' Ulama }\left(^{* *}\right)\end{array}$ \\
\hline 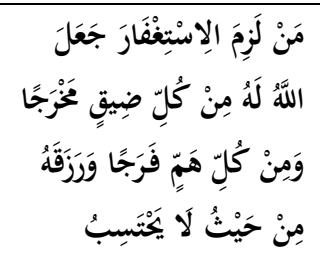 & $\begin{array}{l}\text { Abu Daud - } \\
1297\end{array}$ & $\begin{array}{l}\text { Penjelasan } \\
\text { tentang istighfar }\end{array}$ & $\begin{array}{l}\text { Dha'if menurut } \\
\text { Muhammad } \\
\text { Nashiruddin al- } \\
\text { Albani }\end{array}$ \\
\hline 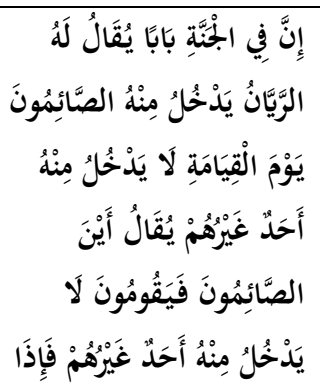 & Bukhari - 1763 & $\begin{array}{l}\text { Pintu surga ar- } \\
\text { Rayyan untuk } \\
\text { orang yang } \\
\text { berpuasa }\end{array}$ & $\begin{array}{l}\text { Shahih menurut } \\
\text { Ijma' Ulama }\left(^{* *}\right)\end{array}$ \\
\hline
\end{tabular}




\begin{tabular}{|c|c|c|c|}
\hline 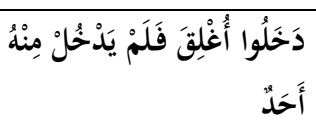 & & & \\
\hline 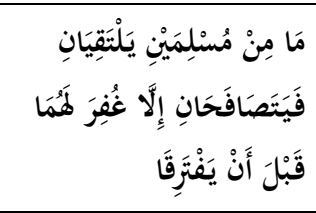 & $\begin{array}{l}\text { Abu Daud - } \\
4536\end{array}$ & $\begin{array}{l}\text { Penjelasan } \\
\text { tentang jabat } \\
\text { tangan }\end{array}$ & $\begin{array}{l}\text { Shahih menurut } \\
\text { Muhammad } \\
\text { Nashiruddin al- } \\
\text { Albani }\end{array}$ \\
\hline 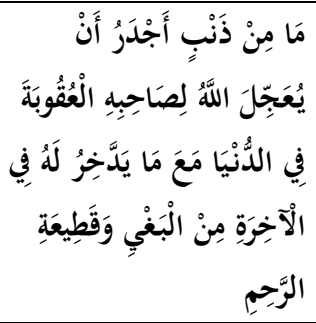 & $\begin{array}{l}\text { Ibnu Majah - } \\
4201\end{array}$ & $\begin{array}{l}\text { Siksaan bagi } \\
\text { pelaku yang } \\
\text { berbuat aniaya } \\
\text { dan } \\
\text { memutuskan tali } \\
\text { silaturrahmi }\end{array}$ & $\begin{array}{l}\text { Shahih menurut } \\
\text { Muhammad } \\
\text { Nashiruddin al- } \\
\text { Albani }\end{array}$ \\
\hline 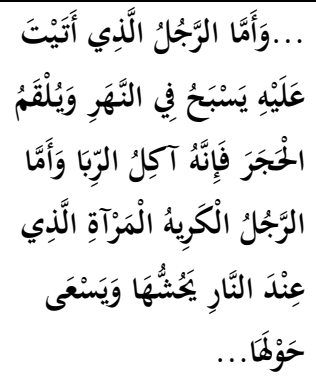 & Bukhari - 6525 & $\begin{array}{l}\text { Orang-orang } \\
\text { yang berada } \\
\text { dalam neraka }\end{array}$ & $\begin{array}{l}\text { Shahih menurut } \\
\text { Ijma' Ulama }\left({ }^{* *}\right)\end{array}$ \\
\hline 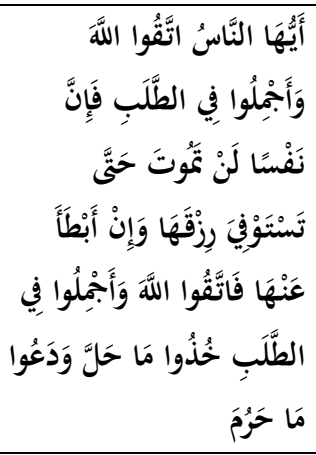 & $\begin{array}{l}\text { Ibnu Majah - } \\
2135\end{array}$ & $\begin{array}{l}\text { Bertakwa } \\
\text { kepada Allah }\end{array}$ & $\begin{array}{l}\text { Shahih menurut } \\
\text { Muhammad } \\
\text { Nashiruddin al- } \\
\text { Albani }\end{array}$ \\
\hline 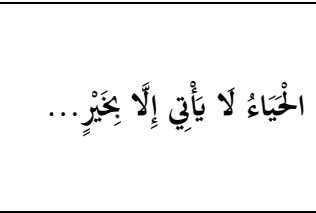 & Bukhari - 5652 & $\begin{array}{l}\text { Sifat malu } \\
\text { terdapat } \\
\text { ketenangan, } \\
\text { ketentraman }\end{array}$ & $\begin{array}{l}\text { Shahih menurut } \\
\text { Ijma' Ulama }\left({ }^{* *}\right)\end{array}$ \\
\hline 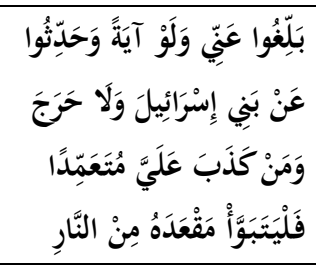 & Bukhari - 3202 & $\begin{array}{l}\text { Perintah } \\
\text { menyampaikan } \\
\text { kebenaran atas } \\
\text { Nabi Saw. }\end{array}$ & $\begin{array}{l}\text { Shahih menurut } \\
\text { Ijma' Ulama }\left({ }^{* *}\right)\end{array}$ \\
\hline 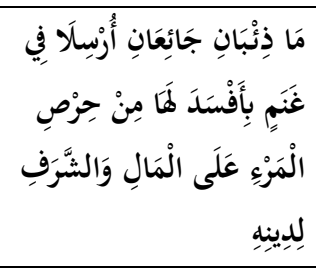 & Tirmidzi - 2298 & $\begin{array}{l}\text { Ambisi } \\
\text { memperoleh } \\
\text { harta dan } \\
\text { kemuliaan yang } \\
\text { merusak agama }\end{array}$ & $\begin{array}{l}\text { Shahih menurut } \\
\text { Muhammad } \\
\text { Nashiruddin al- } \\
\text { Albani }\end{array}$ \\
\hline
\end{tabular}


(*) Penlilaian Ulama $=$ menurut aplikasi ‘Ensiklopedi Hadits 9 Imam' (Android).

$(* *)$ Ijma' Ulama $=$ Menurut Abdul Karim Zaidan, adalah kesepakatan para ulama mujtahid dari kalangan umat Islam (AS, 2014).

Tabel 1.2 menunjukkan lima belas sampel konten hadis yang dibagikan oleh akun ini. Kemudian penulis meneliti kembali hadis-hadis yang terdapat pada konten hadis tersebut. Hasilnya, hadis-hadis yang dibagikan memiliki dua belas kualitas hadis shahih, satu kualitas hadis dha' if dan dua kualitas hadis hasan seperti yang dicantumkan tabel di atas. Dan satu dari lima belas sampel konten hadis, penulis menemukan postingan yang terdapat kejanggalan dalam sanadnya setelah diteliti Kembali yaitu pada postingan Gambar 10.

\section{Gambar 10. Postingan Konten Hadis}

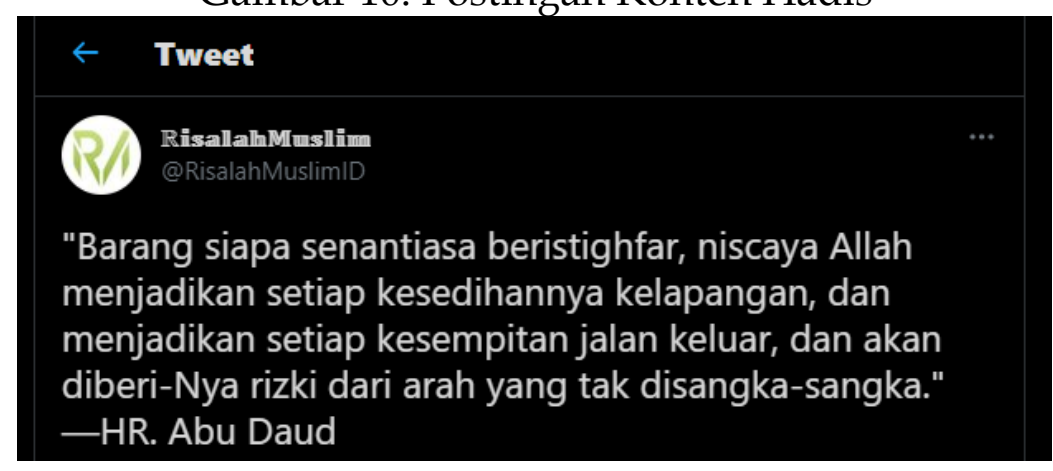

Gambar 10 mendeskripsikan postingan konten hadis yang terdapat kejanggalan dalam sanadnya. Adapun teks asli dari hadis tersebut, yaitu:

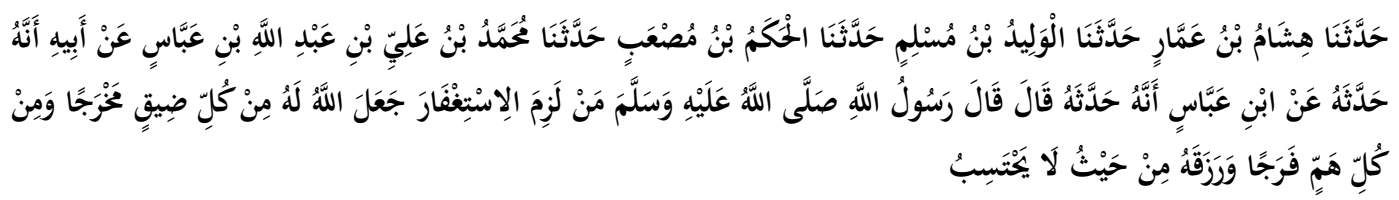

Sunan Abu Daud No. 1297: “Telah menceritakan dari Kami [Hisyam bin 'Ammar], telah menceritakan kepada Kami [al-Walid bin Muslim], telah menceritakan kepada Kami [al-Hakam bin Mush'ab], telah menceritakan kepada Kami [Muhammad bin Ali bin Abdullah bin Abbas] dari [ayahnya] bahwa ia bercerita kepadanya, dari [Ibnu Abbas] bahwa ia bercerita kepadanya, ia berkata; Rasulullah shallAllahu wa'alaihi wa sallam bersabda: "Barang siapa yang senantiasa beristighfar, maka Allah pasti akan selalu memberikannya jalan keluar dari setiap kesempitan dan kelapangan dari segala kegundahan serta Allah akan memberikan rezeki kepadanya dari arah yang tidak ia sangka-sangka" (Daud). 
Dalam hadis tersebut, penulis menemukan dua rawi yaitu, al-Walid bin Muslim dan al-Hakam bin Mush'ab. Penilaian al-Walid bin Muslim para ulama menilai bahwa hafalannya tercampur. Kemudian beliau dinilai sebagai pelaku tadlish (orang yang menyamarkan rawi hadis) dari rawi yang dha'if. Jika ia meriwayatkan dengan menggunakan simbol maka periwayatannya itu tidak bisa dijadikan sebagai hujjah (al-'Ashqalani, 1326). Kemudian rawi al-Hakam bin Mush'ab ini dinilai majhul oleh Abu Hatim dan Ibnu Hajar al-'Ashqalani (al-Ashqalani, 1986). Dengan adanya bukti bahwa al-Walid meriwayatkan dari rawi yang dha'if yaitu Mush'ab maka hadisnya itu tidak bisa dijadikan sebagai hujjah kecuali jika tedapat jalur lain.

Dengan hasil penelitian yang telah dipaparkan dari akun @RisalahMuslimID ini, penulis mengklasifikasikan kelebihan dan kekurangan pada akun ini. Kelebihan pada akun ini, yaitu membagikan konten Islam lain selain hadis berupa potongan ayat dari surah dalam alQur'an, sya'ir, serta kutipan dari sahabat Nabi Saw. dan ulama terkemuka yang diambil dari sebuah kitab. Kemudian, sebagian konten yang dibagikan terdapat desain grafis yang simpel namun tetap menarik untuk memikat pembaca agar tertarik untuk membaca lebih lanjut. Dalam postingan konten hadis, akun ini sebagian mencantumkan struktur hadis yang cukup lengkap, yaitu dengan mencantumkan teks matan hadis, terjemah, mukharrij, serta nomor hadis. Selain itu, akun ini memberikan penjelasan di kolom caption pada konten yang terdapat desain grafis di dalamnya.

Adapun kekurangan pada konten hadis yang dibagikan pada akun ini, yaitu tidak terdapat teks asli dari hadis yang ditujukan, sebagian hanya mencantumkan matan hadisnya saja. Lalu tidak semua konten yang dibagikan mencantumkan kelengkapan sebuah hadis, yaitu sebagian terdapat kualitas serta nomor hadis sebagian lainnya tidak dicantumkan. Dengan begitu, memunculkan keraguan akan hadis-hadis yang dibagikan. Sehingga perlu diteliti kembali kebenaran atas hadis-hadis yang terdapat pada akun ini. Kemudian sampel konten hadis yang penulis ambil, meskipun rata-rata dinilai shahih, akan tetapi masih terdapat hadis yang janggal dari sanadnya dan dinilai dha'if.

\section{c) @thesunnah_path (Instagram)}

Selanjutnya adalah jejaring sosial Instagram. Instagram adalah sebuah layanan jejaring sosial yang berupa aplikasi berbagi foto dan video yang memungkinkan pengguna mengambil foto, mengambil video, menerapkan filter digital, dan membagikannya ke berbagai layanan jejaring sosial, termasuk milik Instagram sendiri. Instagram dirilis perdana pada tanggal 6 Oktober 2010, yang dirancang awal oleh Kevin Systrom, Mike Krieger. 
Namun saat ini, Instagram sudah diambil alih kepemilikannya oleh Facebook, Inc.

Pada jejaring sosial Instagram ini, penulis menemukan sebuah akun yang bernama Wadah Media Dakwah Sunnah dengan nama pengguna @thesunnah_path. Sejauh data yang diambil sampai saat ini, akun tersebut memiliki 9,2 ribu lebih postingan, 721 ribu pengikut, dan 320 mengikuti.

Dari beranda profil akun ini memposting konten Islam berupa foto maupun video dari kutipan ustadz, tokoh ulama terkemuka, serta potongan kalimat dari berbagai kitab. Konten-konten yang dibagikan oleh akun ini memiliki desain yang simpel dan kekinian serta dengan teks di dalamnya. Dengan bertemakan tema Islami, memungkinkan banyak orang memperhatikan untuk dilihat dan dibaca. Selain memberikan keterangan dalam postingan yang terdapat di foto maupun videonya, akun ini juga memberikan informasi lebih detail dalam caption.

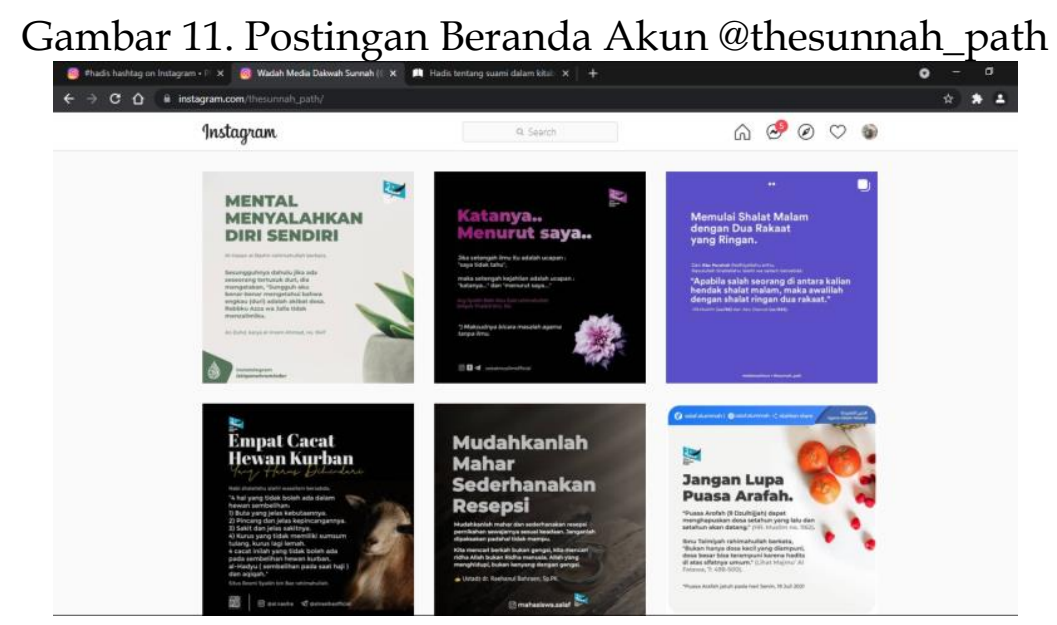

Gambar 11 mendeskripsikan postingan yang dibagikan oleh pemilik akun @thesunnah_path dengan sebuah foto dan desain grafis yang berupa teks terkait hadis di dalamnya. Kemudian penulis mengambil sampel konten hadis dalam satu bulan terakhir yaitu berjumlah 108 postingan. Dengan teknik proporsional random sampling yang diungkapkan oleh Arikunto sebelumnya, maka penulis mengambil $10 \%$ dari jumlah postingan yakni 10,8 atau digenapkan menjadi 11 postingan konten hadis yang bisa dilihat dalam tabel berikut:

Tabel 1.3. Sampel Hadis pada Akun @thesunnah_path

\begin{tabular}{|c|c|c|c|}
\hline Hadis & $\begin{array}{l}\text { Hadis Riwayat } \\
\text { - Nomor Hadis }\end{array}$ & Bab & $\begin{array}{l}\text { Penilaian } \\
\text { Ulama }(*)\end{array}$ \\
\hline 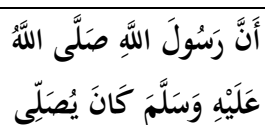 & Muslim - 1215 & $\begin{array}{l}\text { Shalat malam } \\
\text { dan jumlah }\end{array}$ & $\begin{array}{l}\text { Shahih menurut } \\
\left.\text { Ijma' Ulama }{ }^{* *}\right)\end{array}$ \\
\hline
\end{tabular}




\begin{tabular}{|c|c|c|c|}
\hline 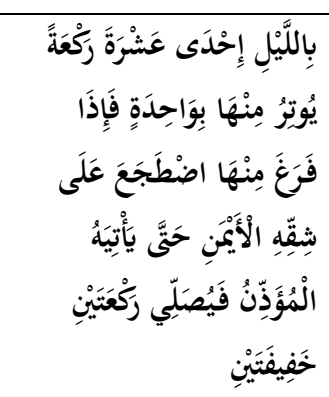 & & $\begin{array}{l}\text { raka'at Nabi } \\
\text { Saw. }\end{array}$ & \\
\hline 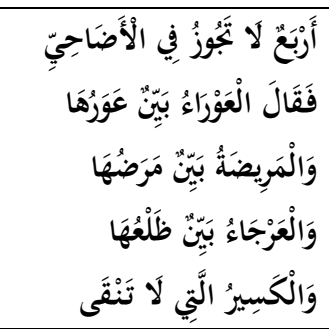 & $\begin{array}{l}\text { Abu Daud - } \\
2420\end{array}$ & $\begin{array}{l}\text { Hewan kurban } \\
\text { yang tidak boleh }\end{array}$ & $\begin{array}{l}\text { Shahih menurut } \\
\text { Muhammad } \\
\text { Nashiruddin al- } \\
\text { Albani }\end{array}$ \\
\hline 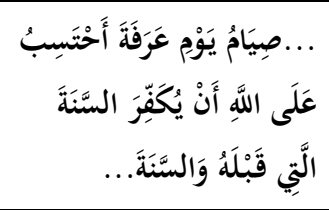 & Muslim - 1976 & $\begin{array}{l}\text { Anjuran puasa } \\
\text { tiga hari dalam } \\
\text { setiap bulan } \\
\text { (Puasa Arafah) }\end{array}$ & $\begin{array}{l}\text { Shahih menurut } \\
\text { Ijma' Ulama }\left({ }^{* *}\right)\end{array}$ \\
\hline 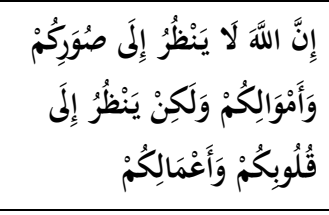 & Muslim - 4651 & \begin{tabular}{|l} 
Haramnya \\
berlaku zalim \\
kepada sesama \\
muslim \\
\end{tabular} & $\begin{array}{l}\text { Shahih menurut } \\
\text { Ijma' Ulama }\left(^{* *}\right)\end{array}$ \\
\hline 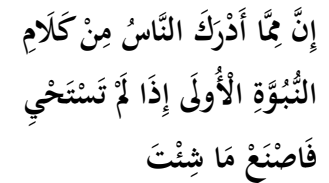 & Bukhari - 5655 & $\begin{array}{l}\text { Jika kamu tidak } \\
\text { malu }\end{array}$ & $\begin{array}{l}\text { Shahih menurut } \\
\left.\text { Ijma' Ulama }{ }^{* *}\right)\end{array}$ \\
\hline 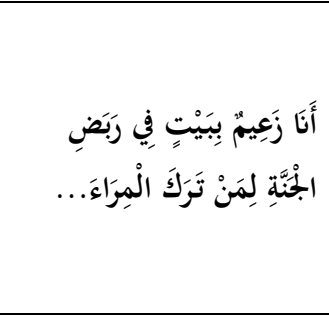 & $\begin{array}{l}\text { Abu Daud - } \\
4167\end{array}$ & \begin{tabular}{|l|} 
Nabi Saw. \\
menjamin \\
rumah di surga \\
bagi yang \\
meninggalkan \\
perdebatan \\
\end{tabular} & $\begin{array}{l}\text { Hasan menurut } \\
\text { Muhammad } \\
\text { Nashiruddin al- } \\
\text { Albani }\end{array}$ \\
\hline 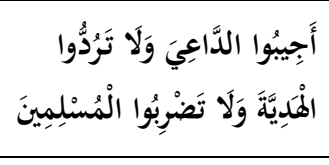 & Ahmad - 3645 & $\begin{array}{l}\text { Tiga hak } \\
\text { terhadap sesama } \\
\text { muslim }\end{array}$ & $\begin{array}{l}\text { Hasan menurut } \\
\text { Syu'aib al- } \\
\text { Arna'uth }\end{array}$ \\
\hline 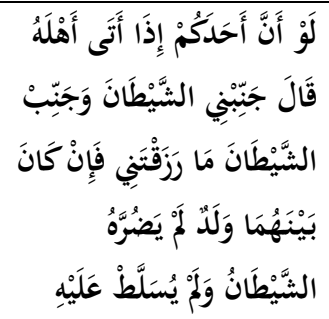 & Bukhari - 3041 & $\begin{array}{l}\text { Sifat iblis dan } \\
\text { tentaranya }\end{array}$ & $\begin{array}{l}\text { Shahih menurut } \\
\text { Ijma' Ulama }\left(^{* *}\right)\end{array}$ \\
\hline
\end{tabular}




\begin{tabular}{|c|c|c|c|}
\hline 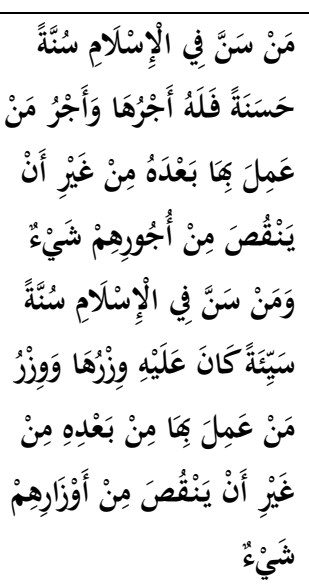 & Muslim - 1691 & $\begin{array}{l}\text { Dorongan untuk } \\
\text { sedekah } \\
\text { meskipun } \\
\text { dengan setengah } \\
\text { biji kurma atau } \\
\text { kalimat yang } \\
\text { baik }\end{array}$ & $\begin{array}{l}\text { Shahih menurut } \\
\text { Ijma' Ulama }\left(^{* *}\right)\end{array}$ \\
\hline 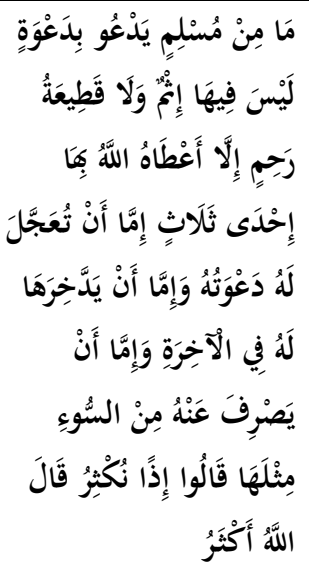 & Ahmad - 10709 & $\begin{array}{l}\text { Tiga hal dari } \\
\text { Allah pada } \\
\text { orang yang } \\
\text { memanjatkan } \\
\text { do'a selama } \\
\text { tidak } \\
\text { mengandung } \\
\text { dosa }\end{array}$ & $\begin{array}{l}\text { Hasan menurut } \\
\text { Syu'aib al- } \\
\text { Arna'uth }\end{array}$ \\
\hline 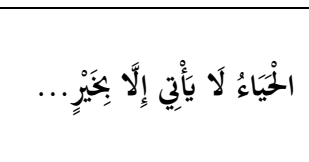 & Bukhari - 5652 & $\begin{array}{l}\text { Rasa malu } \\
\text { mendatangkan } \\
\text { kebaikan }\end{array}$ & $\begin{array}{l}\text { Shahih menurut } \\
\text { Ijma' Ulama }\left(^{* *}\right)\end{array}$ \\
\hline
\end{tabular}

(*) Penlilaian Ulama $=$ menurut aplikasi 'Ensiklopedi Hadits 9 Imam' (Android).

(**) Ijma' Ulama = Menurut Abdul Karim Zaidan, adalah kesepakatan para ulama mujtahid dari kalangan umat Islam (AS, 2014).

Tabel 1.3. menunjukkan sebelas sampel konten hadis yang dibagikan. Kemudian penulis meneliti kembali hadis-hadis yang terdapat pada konten hadis tersebut. Hasilnya yang terdapat pada tabel di atas, bahwa terdapat hadis yang dinilai shahih dan hasan. Bahkan dalam caption mencantumkan keterangan yang sangat terperinci. Walaupun tidak mencantumkan sanad asli dari awal hingga Nabi Saw., namun terdapat unsur hadis lain yaitu berupa teks asli matan hadis, terjemah, mukharrij yang meriwayatkan, nomor hadis, serta syarh dari hadis tersebut dengan keterangan dari sumbernya pula. Lebih lanjut, dalam kolom komentar terdapat beberapa akun yang bertanya terkait konten yang dibagikannya. Meski begitu, para pengguna Instagram lain banyak berinisiatif untuk memberikan jawaban yang tidak menyesatkan orang lain. 


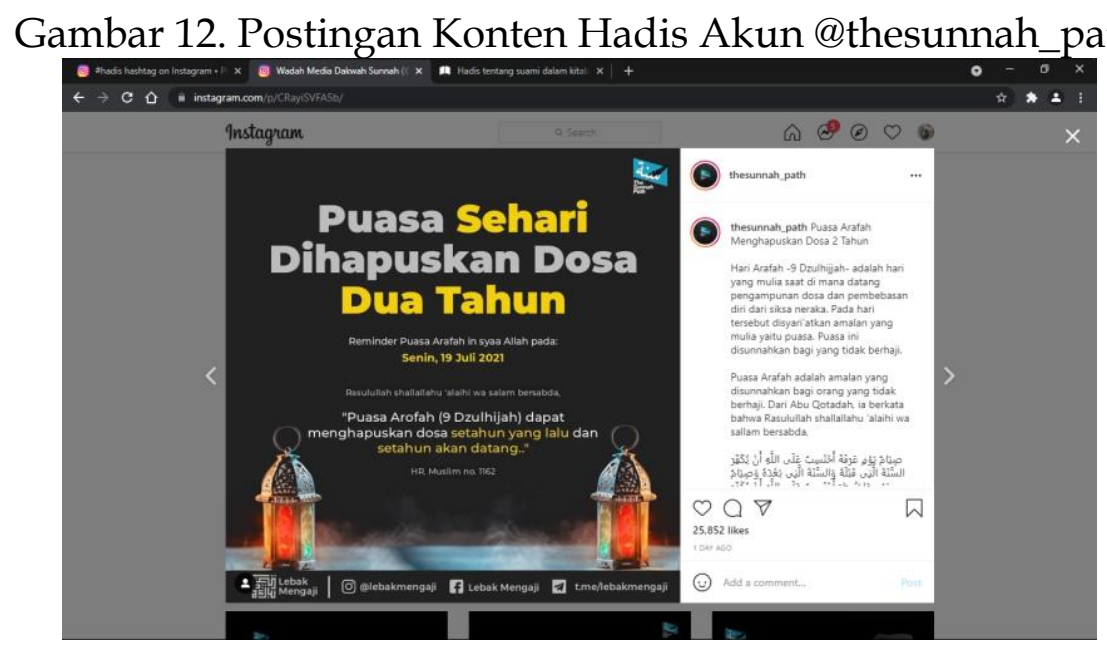

Gambar 11 mendeskripsikan salah satu postingan konten hadis pada akun@thesunnah_path. Adapun teks asli dari hadis tersebut yaitu:

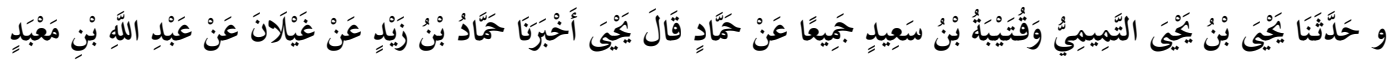

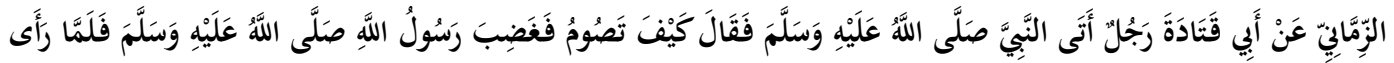

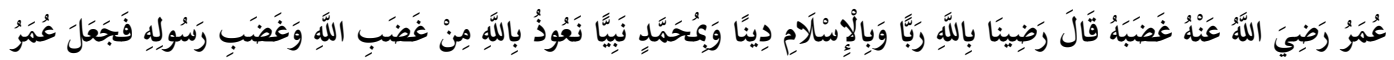

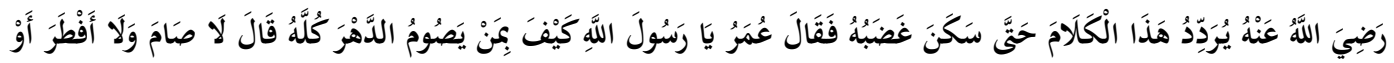

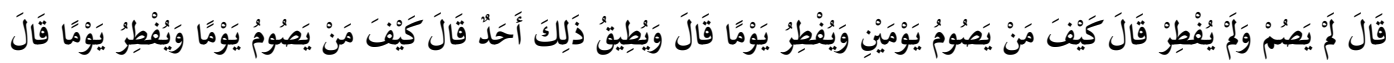

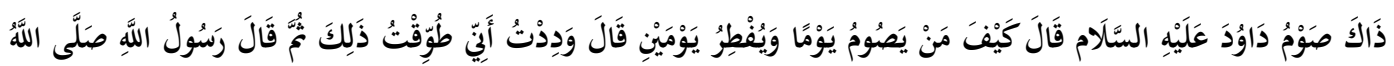

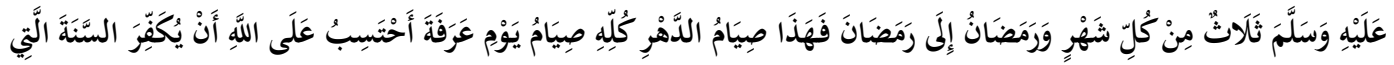

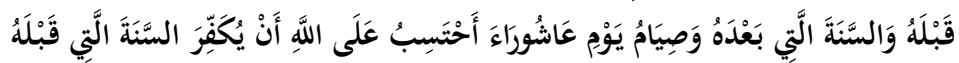

Shahih Muslim No. 1976: "Dan Telah menceritakan kepada kami [Yahya bin Yahya At-Tamimi] dan [Qutaibah bin Sa'id] semuanya dari [Hammad] - [Yahya] berkata- telah mengabarkan kepada kami [Hammad bin Zaid] dari [Ghailan] dari [Abdullah bin Ma'bad az-Zimani] dari [Abu Qatadah] bahwa seorang laki-laki datang kepada Nabi shallallahu 'alaihi wasallam dan bertanya, "Bagaimanakah Anda berpuasa?" Mendengar pertanyaan itu, Rasulullah shallallahu 'alaihi wasallam marah. Dan ketika Umar menyaksikan Rasulullah shallallahu 'alaihi wasallam marah, ia berkata, "Kami rela Allah sebagai Tuhan, Islam sebagai agama dan Muhammad sebagai Rasul. Kami berlindung kepada Allah, dari murka Allah dan Rasul-Nya." Umar mengulang ucapan tersebut hingga kemarahan Rasulullah shallallahu 'alaihi wasallam reda. Kemudian ia bertanya, "Wahai Rasulullah, bagaimana dengan orang yang berpuasa sepanjang tahun?" Beliau menjawab: "Dia tidak berpuasa dan tidak juga berbuka." -atau beliau katakan dengan redaksi 'Selamanya ia tak dianggap 
berpuasa dan tidak pula dianggap berbuka-- Umar bertanya lagi, "Bagaimana dengan orang yang berpuasa sehari dan berbuka sehari?" beliau menjawab: "Itu adalah puasa Dawud 'Alaihis Salam." Umar bertanya lagi, "Bagaimana dengan orang yang berpuasa sehari dan berbuka dua hari?" beliau menjawab: "Aku senang, jika diberi kekuatan untuk itu." kemudian Rasulullah shallallahu 'alaihi wasallam bersabda: "puasa tiga hari setiap bulan, puasa dari Ramadlan ke Ramadlan sama dengan puasa setahun penuh. Sedangkan puasa pada hari Arafah, aku memohon pula kepada Allah, agar puasa itu bisa menghapus dosa setahun setahun penuh sebelumnya dan setahun sesudahnya. Adapun puasa pada hari 'Asyura', aku memohon kepada Allah agar puasa tersebut bisa menghapus dosa setahun sebelumnya" (Muslim).

Dengan hasil penelitian yang telah dipaparkan dari akun @thesunnah_path, penulis mendapatkan kelebihan serta kekurangan pada akun ini. Kelebihan pada konten dibagikan oleh akun ini, yaitu selain membagikan konten mengenai hadis, akun ini juga membagikan konten Islam lainnya, berupa sebuah foto maupun video dari kutipan ustadz dan tokoh ulama terkemuka, serta konten yang terdapat potongan ayat dari sebuah surah dalam al-Qur'an. Selain itu, konten-konten tersebut dibungkus dengan desain grafis yang minimalis mengikuti tren desain saat ini. Ditambah lagi setiap desain grafis yang ada, dibuat dengan font yang besar, memungkinkan untuk menarik perhatian pengguna Instagram untuk klik konten tersebut. Sehingga membuat para pembaca tertarik untuk membaca isi kontennya. Selain itu, kelebihan konten hadis yang dibagikan oleh akun ini mencantumkan penjelasan yang lebih rinci dan struktur sebuah hadis yang cukup lengkap. Ditambah lagi, pemilik akun ini mencantumkan syarh hadis dan sumber hadis itu didapat dari sumber yang terpercaya dalam caption yang jarang sekali orang lain mencantumkannya. Di samping itu, bila ada pengguna Instagram bertanya pada kolom komentar, akun ini menjawab dengan cukup jelas dan pula mencantumkan sumber.

Adapun kekurangan konten hadis yang dibagikan oleh akun ini, yaitu tidak lengkapnya sanad yang dicantumkan dari awal hingga Nabi Saw., begitu pun dengan teks asli dari sebuah hadis.

\section{Kesimpulan}

Jejaring sosial Facebook, Twitter, dan Instagram merupakan beberapa aplikasi media sosial yang sering kali digunakan oleh para pengguna internet saat ini. Segala informasi tersebar luas di berbagai penjuru dunia, termasuk informasi mengenai hadis dalam bentuk sebuah konten. Pada abad ke-21 ini pemahaman akan hadis secara kontekstualisasi santer dilakukan. Dengan semakin majunya perkembangan teknologi, pencarian 
mengenai hadis para pengguna internet dengan mudah mendapatkan hadis yang diinginkannya. Dilihat dari akun-akun yang penulis teliti, konten hadis yang dibagikan memiliki jumlah like serta komentar yang cukup banyak. Selain itu para pengguna internet tidak hanya melihat, berkomentar, dan menekan tombol like konten hadis yang dibagikan, akan tetapi mereka juga membagikan kembali konten yang mereka dapatkan untuk ruang lingkup mereka sendiri. Meskipun begitu, dengan perkembangan teknologi yang kian maju, tidak dapat dipungkiri adanya sisi kekurangan, khususnya terkait dengan pemahaman hadis maupun kualitas hadis tersebut. Setelah dilakukan kajian terhadap konten-konten hadis yang terdapat pada akun-akun tersebut dengan menggunakan metode content analysis dapat diketahui bahwa konten hadis yang ditemukan tidak selalu dinilai shahih ataupun hasan, beberapa ada yang dinilai dha'if. Bentuk dari konten hadis yang dibagikan juga beragam. Sebagian besar dari ketiga akun tersebut mencantumkan matan, mukharrij, nomor hadis serta kualitas hadis. Sebagian lainnya mencantumkan sanad hingga teks Arab dari hadis tersebut. Walaupun begitu, konten-konten hadis yang dibagikan oleh akun-akun tersebut memiliki desain grafis yang simpel namun menarik, sehingga para pengguna internet tertarik untuk melihat konten tersebut. Penelitian ini diharapan memiliki implikasi manfaat bagi pengembangan khazanah pengetahuan Islam khususnya dalam bidang kajian hadis. Penulis mengakui bahwa penelitian ini memiliki keterbatasan dalam pencarian latar belakang akun yang bertanggung jawab menyebarkan konten hadis di media sosial sehingga diperlukan penelitian lebih lanjut secara komprehensif, integral dan mendalam. Penelitian ini merekomendasikan diadakannya penelitian lebih dalam terutama bagi para pengkaji hadis dengan keilmuan lain yang akan membuka pemahaman yang lebih luas mengenai topik ini.

\section{Daftar Pustaka}

al-'Ashqalani, I. H. (1326). Tahdzibul Tahdzib. Al-Hin: Mathbu'ah Dairoh Ma'arif an-Nadlomiyyah.

al-Ashqalani, I. H. (1986). Taqribut Tahdzib. Suriah: Dar ar-Rasyid.

Al-Ayyubi, M. Z. (2019). Etika Bermedia Sosial Dalam Menyikapi Pemberitaan Bohong (Hoax) Perspektif Hadis. Jurnal Studi Ilmu-ilmu Al-Qur'an dan Hadis, 19(2), 148-166.

al-Qardhawi, Y. (1999). Bagaimana Memahami Hadis Nabi SAW. Bandung: Karisma.

Aris, A., \& Iskandar, I. (2016). Tinjauan Komunikasi Islam Tentang Dampak Jejaring Sosial Facebook (Kasus pada Mahasiswa Stain Parepare. KOMUNIDA: Media Komunikasi dan Dakwah, 6(2), 62-81.

Asur, S., \& Huberman, B. A. (2010). Predicting the Future With Social Media. Social Computing Lab, 1. 
Darmalaksana, W. (2004). Hadis di Mata Orientalis: Telaah atas Pandangan Ignaz Goldziher dan Joseph Schacht. Bandung: Benang Merah Press.

Darmalaksana, W. (2020). Formula Penelitian Pengalaman Kelas Menulis. Kelas Menulis UIN Sunan Gunung Djati Bandung, 1-8.

Darmalaksana, W. (2020). Takhrij dan Syarah Hadis Agro Teknologi: Studi Tumbuhan Daun Senna dalam Infeksi Covid-19. Digital Library UIN Sunan Gunung Djati Bandung, 2.

Darmalaksana, W., Pahala, L., \& Soetari, E. (2017). Kontroversi Hadis sebagai Sumber Hukum Islam. Wawasan: Jumal Ilmiah Agama Dan Sosial Budaya, 2(2), 245-258.

Dawud, A. (1998). Sunan Abu Dawud. Beirut: Dar Ibn Hazm.

Edosomwan, S., Prakasan, S. K., Kouame, D., Watson, J., \& Seymour, T. (2011). The history of social media and its impact on business. Journal of Applied Management and entrepreneurship, 16(3), 79-91.

Fahmi, R. M. R., Aeres, I., Wibawa, I. M. C. T., \& Dalimunthe, R. P. (2021). A Silaturahmi Melalui Media Sosial Perspektif Hadits. AL-HIKMAH (Jurnal Pendidikan dan Pendidikan Agama Islam), 3(2), 214-225.

Fahrimal, Y. (2018). Netiquette: Etika Jejaring Sosial Generasi Milenial Dalam Media Sosial. Jurnal Penelitian Pers Dan Komunikasi Pembangunan, 22(1), 69-78.

Ferdiansyah, H. (2017, Desember 1). Pembagian Hadits Ditinjau dari Kualitasnya. Retrieved from nuonline: https:/ / islam.nu.or.id/post/read/83811/pembagian-hadits-ditinjaudari-kualitasnya

Ferlitasari, R. (2018). Pengaruh Media Sosial Instagram Terhadap Perilaku Keagamaan Remaja (Studi pada Rohis di SMA Perintis 1 Bandar Lampung) (Doctoral dissertation, UIN Raden Intan Lampung).

Handoko, K. K. (2017). Evaluasi Praktik Corporate Social Responsibility Dengan Konsep Ideal Global Reporting Initiative Pada Perusahaan-Perusahaan Yang Terdaftar Di Bursa Efek Indonesia Pada Tahun 2015 (Doctoral dissertation, Universitas Katolik Soegijapranata Semarang).

Hibban, I. (1973). Ats-Tsiqat. Abad: Da'irah al-Ma'arif al-'Utsmaniyyah bi Haidar.

Ismail, M. S. (1994). Hadis Nabi yang Tekstual dan Kontekstual: Telaah Ma'anil al-Hadits tentang Ajaran Islam yang Universal, Temporal dan Lokal. Jakarta: Bulan Bintang.

Kosasih, E., Raharusun, A. S., Dalimunthe, R. P., \& Kodir, A. A. (2020). Literasi Media Sosial dalam Permasyarakatan Moderasi Beragama dalam Situasi Pandemi Covid 19. Digital Library UIN Sunan Gunung Djati Bandung, 3.

Luthfie, N. (2016, November 2). Menyaring Informasi di Media Sosial. Retrieved from tirto.id: https://tirto.id/menyaring-informasi-dimedia-sosial-b1np 
Mayfield, A. (2008). What is Social Media. Indian Strategic Knowledge Online, 79.

Mulyati, A. (2014). Panduan Optimalisasi Media Sosial untuk Kementrian Perdagangan RI. Jakarta: Pusat Humas Kementrian Perdagangan.

Muslim, I. (1993). Shahih Muslim. Beirut: Dar al-Fikr.

Saputra, T. A., \& Suryadilaga, M. A. (2020). Perkembangan dan Kesahihan Hadis dari Awal Islam Hingga Zaman Post Truth. Jurnal Ilmiah AlMu'ashirah.

Soetari, E. (1994). Ilmu Hadits. Bandung: Amal Bakti Press.

Solahudin, M. A., \& Suyadi, A. (2009). Ulumul Hadis. Bandung: CV Pustaka Setia.

Sosiawan, E. A. (2020). Penggunaan situs jejaring sosial sebagai media interaksi dan komunikasi di kalangan mahasiswa. Jurnal Ilmu Komunikasi, 9(1), 60-75.

Sumadi, E. (2016). Dakwah dan Media Sosial: Menebar Kebaikan Tanpa Diskrimasi. Komunikasi Penyiaran Islam, 1(1), 173-190.

Susiadi, A. S. (2014). Ijma' dan Issu Kotemporer. ASAS, 6(2).

Syifana, D. I., \& Pratama, F. (2021). Perkembangan Kajian Hadis Di Indonesia Pada Abad 20-21 M. Jurnal UIN Sunan Ampel Surabaya.

Umara, A. F. (2021, Januari 19). Hadis Sahih, Hasan, dan Dhaif. Retrieved from Asosiasi Ilmu Hadis Indonesia:

https://www/asilha.com/2021/01/19/hadis-sahih-hasan-dandhaif/

Westerman, D., Spence, P. R., \& Heide, B. V. (2012). A social network as information: The effect of system generated reports of connectedness on credibility on Twitter. Computers in Human Behavior.

Yusrintosepu. (2018, April 23). Media Sosial E Jejaring Sosial (Perbedaan dan Klasifikasinya). Retrieved from slideshare: https://www.slideshare.net/yusrintosepu/media-sosial-jejaringsosial-perbedaan-dan-klasifikasinya 